\title{
PRESPEKTIF PRAKTEK \\ KEBIJAKAN SUBSIDI DALAM KAITANNYA DENGAN RENCANA PENYEMPURNAAN KEBIJAKAN SUBSIDI PUPUK MENUJU KEDAULATAN PANGAN DI INDONESIA
}

\author{
Heliaantoro \& Prof. Hikmahanto Juwana, S.H., LL.M., Ph.D \\ Kandidat Doktor Fakultas Hukum Universitas Padjajaran \\ Email: Toro1940@gmail.com
}

\begin{abstract}
ABSTRAK
Pada RAPBN 2017, terdapat alokasi subsidi bidang pertanian yang terdiri atas subsidi pupuk, subsidi benih dan subsidi bunga kredit program. Secara agregat jumlah alokasi bidang pertanian ini mengalami peningkatan dari tahun sebelumnya. Pemerintah telah mengeluarkan anggaran yang besar untuk kepentingan bidang pertanian, tentunya pemerintah berharap sekali agar kebijakan tersebut dapat memberikan dampak yang positif dan signifikansi terhadap pembangunan sektor pertanian di Indonesia. Subsidi pertanian menjadi instrumen kebijakan distributif pemerintah yang penting dalam membangun sektor pertanian. Implementasi kebijakan subsidi diselenggarakan untuk meningkatkan kapasitas produksi petani serta bentuk komitmen pemerintah dalam mewujudkan swasembada pangan. dalam kebijakan perpupukan Indonesia, mulai dari pengertian petani yang menjadi objek subsidi pupuk itu sendiri sampai dengan subsidi pupuk beserta aturan-aturan hukum positif yang mengatur tentang subsidi mulai dari pendataan, penganggaran, penyaluran dan pengawasan masih rentan terhadap permasalah di lapangan, mulai dari definisi petani yang tidak jelas, penyaluran pupuk bersubsidi seringkali mendahului alokasinya, implementasi kebijakan subsidi pupuk masih menemui kendala dan permasalahan pada aspek pendataan, aspek penganggaran,serta aspek pengawasan yang belum dijalankan fungsinya secara optimal.
\end{abstract}

Kata kunci: Kebijakan Subsidi, Pupuk, Kedaulatan Pangan .

\begin{abstract}
ABSTACT
In RAPBN 2017, there is an allocation of subsidies in agriculture consisting of fertilizer subsidies, seed subsidies and credit interest subsidy programs. In aggregate the number of allocations in the agricultural sector has increased from the previous year. The government has issued a large budget for the interests of agriculture, of course, the government is very hopeful that the policy can have a positive impact and significance to the development of the agricultural sector in Indonesia. Agricultural subsidies are an instrument of government distributive policy that is important in developing the agricultural sector. The implementation of the subsidy policy is held to increase the production capacity of farmers and the government's commitment to achieve food selfsufficiency. in the Indonesian fertilization policy, ranging from the understanding of the farmers who become the object of subsidizing the fertilizer itself to fertilizer subsidies along with positive legal rules governing subsidies ranging from data collection, budgeting, distribution and supervision are still vulnerable to problems in the field, ranging from the definition of farmers which is not clear, the distribution of subsidized fertilizers often precedes the allocation, the implementation of subsidized fertilizer
\end{abstract}


policy still encountered obstacles and problems in the aspect of data collection, budgeting aspect, and supervision aspects that have not yet functioned optimally.

Keywords: Subsidies Policy, Fertilizer, Food Sovereignty.

\section{Pendahuluan}

Sektor pertanian mempunyai peranan yang penting dan strategis dalam membangun sebuah bangsa. Peranan sektor pertanian antara lain dalam meningkatkan penerimaan devisa negara, penyediaan lapangan kerja, perolehan nilai tambah dan daya saing ekonomi, pemenuhan kebutuhan konsumsi pokok dalam negeri, bahan baku industri dalam negeri serta optimalisasi pengelolaan sumber daya alam secara berkelanjutan. Secara ekonomis peran sektor pertanian juga dapat dilihat dalam besarnya kontribusi sektor pertanian terhadap Produk Domestik Bruto (PDB) masih sangat penting dan diharapkan dari tahun ke tahun terus mengalami peningkatan (Peraturan Menteri PertanianNo.19/Permentan/HK.140/4/ 2015 tentang Rencana Strategis Kementrian Pertanian 2015 -2019). Sehingga tidak mengherankan dalam setiap pergantian presiden, masalah pertanian ini selalu menjadi program yang menjadi bidikan dalam program kerja presiden (Pada program kabinet kerja Presiden ke 7, Presiden Djoko Widodo, diamanatkan dalam nawa cita butir ke 2 yaitu visi pemerintah bidang pertanian adalah menuju kedaulatan pangan).

Dalam RAPBN 2017, terdapat alokasi subsidi bidang pertanian yang terdiri atas subsidi pupuk, subsidi benih dan subsidi bunga kredit program. Secara agregat jumlah alokasi bidang pertanian ini mengalami peningkatan dari tahun sebelumnya (RAPBN 2016). Pemerintah telah mengeluarkan anggaran yang besar untuk kepentingan bidang pertanian, tentunya pemerintah berharap sekali agar kebijakan tersebut dapat memberikan dampak yang positif dan signifikansi terhadap pembangunan sektor pertanian di Indonesia. Karena pencapaian keinginan pemerintah tersebut tentunya harus dibarengi dengan dukungan tatakelola kebijakan yang efektif dari waktu kewaktu. Nampaknya hal itu telah dilakukan oleh pemerintah antara lain dengan peninjauan kebijakan subsidi khususnya pupuk selama beberapa kali, dan terakhir dengan rencana akan dikeluarkan kebijakan subsidi langsung melalui kebijakan "kartu tani" berupa vaucer untuk penebusan pupuk oleh para petani di Indonesia di tahun 2018 ini.

Seperti disampaikan sebelumnya subsidi pertanian menjadi instrumen kebijakan distributif pemerintah yang penting dalam membangun sektor pertanian. Implementasi kebijakan subsidi diselenggarakan untuk meningkatkan kapasitas produksi petani serta bentuk komitmen pemerintah dalam mewujudkan swasembada pangan. Kebijakan pemerintah dalam sektor pertanian tanaman pangan, dilaksanakan secara menyeluruh dari hulu sampai hilir. Pada sektor hulu, pemerintah mendorong produksi tanaman pangan dengan menyediakan input yang bersubsidi (benih, pupuk, pestisida) melalui mekanisme pemberian subsidi terhadap produsen input produksi tersebut. Pada proses produksi, pemerintah juga melaksanakan kebijakan bantuan modal dan pelatihan sistem usahatani. Pada sektor hilir pemerintah menerapkan 
kebijakan pengaturan harga jual komoditas tanaman pangan.

Dengan banyaknya kebijakan yang dituangkan dalam ketentuan pemerintah, seringkali ketentuan yang dibuat tidak secara pas dapat membidik sasaran yang sama, karena pengertian sasaran kebijakan masih belum dapat menggambarkan secara tepat objek yang dituju.

Di dalam kebijakan perpupukan Indonesia, mulai dari pengertian petani yang menjadi objek subsidi pupuk itu sendiri sampai dengan subsidi pupuk beserta aturan-aturan hukum positif yang mengatur tentang subsidi mulai dari pendataan, penganggaran, penyaluran dan pengawasan masih rentan terhadap permasalah di lapangan, Dari definisi petani saja misalnya, pemerintah sudah membuat definisi yang tidak pas mengenai objek subsidi pertanian, ada penyebutan pengertian "korporasi" yang juga didefinisi untuk mendapat subsidi. Jika korporasi diberi subsidi, jelas tidak tepat. Seperti yang dicontohkan dalam definisi "petani penerima pupuk subsidi" yang tertuang dalam Bab 1, Pasal 1 butir 10 UndangUndang No 16/2006 tentang sistem penyuluhan pertanian, perikanan dan kehutanan:

"Petani adalah perorangan warga Negara Indonesia beserta keluarganya atau korporasi yang mengelola usaha di bidang pertanian, wanatani, minatani, agropasture, penangkaran satwa dan tumbuhan, didalam dan disekitar hutan, yang meliputi usaha hulu, usaha tani, agroindustry, pemasaran dan jasa penunjang."

Regulasi ini dapat menimbulkan kontroversial, jika 30 persen subsidi pupuk diberikan ke korporasi, petani tidak akan dapat apa-apa, dan ini akan memberi dampak yang serius. ketika sasaran penerima subsidi tidak didefinisikan secara lugas dan jelas, maka penyaluran pupuk bersubsidi akan berdampak pada pupuk tidak sampai kepada "petani" yang sesungguhnya dan akan menjadi lebih tidak tepat jumlah, tidak tepat harga, tidak tepat tempat, tidak tepat waktu, tidak tepat mutu dan tidak tepat sasaran (sasaran 6 tepat) (Herman, A.S;2005). Belum lagi masalah yang krusial lainnya seperti penyaluran pupuk bersubsidi seringkali mendahului alokasinya, melebihi Rencananya, penyaluran di atas Harga Eceran Tertinggi dan permasalahan lain di tingkat pengecer, ditemukan indikasi penjualan pupuk dengan harga diatas HET, penjualan pupuk kepada petani yang tidak terdaftar dalam RDKK, tidak terpasangnya spanduk pengumuman harga, penyaluran pupuk yang tidak sesuai dengan DO, keterlambatan distribusi, kelangkaan, penggantian kemasan, penimbunan, penjualan di luar wilayah distribusi, serta terdapat beberapa pengecer yang tidak resmi.

Selain itu, selama periode 20092011 implementasi kebijakan subsidi pupuk masih menemui kendala dan permasalahan pada aspek pendataan, terkait tidak validnya data Rencana Definitif Kebutuhan Kelompok (RDKK), di mana terdapat penggelembungan terdapat (mark up) luas lahan dan jumlah petani.

Sementara pada aspek penganggaran, ditemukan audit yang mengoreksi jumlah perhitungan subsidi karena masih terdapatnya sejumlah pupuk delivery order (DO) yang belum disalurkan. Selain itu dalam penghitungan subsidi, masih terdapat biaya-biaya yang tidak termasuk komponen-komponen produksi dalam perhitungan Harga Pokok Penjualan (HPP) yang dijadikan sebagai dasar perhitungan nilai subsidi pupuk. 
Sedangkan aspek pengawasan, Komisi Pengawas Pupuk dan Pestisida (KPPP) baik pada tingkat propinsi maupun kabupaten, belum menjalankan fungsi pengawasan secara optimal.

Atas pemikiran latar belakang itulah maka penelitian ini yang akan dikaji adalah bagaimana kondisi kebijakan serta kontribusi subsidi pupuk pemerintah terhadap kesejahteraan petani sebagai jaminan ketahanan pangan nasional.

\section{Pengertian Subsidi}

Subsidi dapat didefinisikan sebagai sejumlah bantuan keuangan dari dana pemerintah untuk membantu sektor industri ataupun bisnis guna menjaga harga barang atau jasa tetap rendah. Sedangkan menurut World Trade Organization (WTO), subsidi diartikan sebagai transfer dana langsung termasuk potential transfer seperti loan guarantees, pendapatan yang hilang, barang dan jasa yang disediakan pemerintah. Oleh sebab itu subsidi menjadi alternatif kebijakan politik untuk mentransfer sebagian dana dari kelompok masyarakat yang satu ke kelompok masyarakat lainnya (Badan Perencanaan Pembangunan Nasional, 2007) .

Bagi negara-negara maju, sektor pertanian merupakan salah satu sektor ekonomi utama yang mendapatkan subsidi. Pemilihan sektor ini bukan tanpa dasar, karena dibandingkan sektor ekonomi lainnya, sektor pertanian di negara-negara maju memiliki daya saing yang relatif kurang baik. Oleh karena itu, sebagai bagian integral untuk memproteksi serbuan produk pertanian asing sekaligus memastikan eksistensi sektor pertanian domestik, maka subsidi pertanian tersebut diberikan. Dengan begitu, tampak bahwa subsidi pertanian selain sebagai salah satu strategi untuk melaksanakan

perdagangan

internasional juga lebih bermakna meningkatkan produktivitas masyarakat daripada memenuhi kebutuhan konsumsi semata (Yustika;2008).

Kebijakan subsidi masih merupakan salah satu aspek yang dapat meningkatkan dayasaing komoditas pertanian suatu negara. Pembangunan pertanian masih menjadi upaya strategis pemerintah dalam memenuhi kebutuhan pangan, mengentaskan kemiskinan, mengurangi pengangguran, menghilangkan malnutrisi, dan menghilangkan disparitas ekonomi antar wilayah (World Bank;2009).

\section{Kajian kebijakan pupuk disejumlah negara.}

Kajian mengenai praktek subsidi in put (pupuk) dapat disebutkan antara lain di Malawi dengan menggunakan sisgtem voucher. Sistem voucer membuat para petani membeli dua karung pupuk ukuran 50 kg dengan harga $28 \%$ daru harga totalnya. Sri Lanka menerapkan program yang bertujuan untuk memastikan para petani dapat membeli pupuk dengan harga yang tetap

Pemerintah membayar subsidi kepada i mportir sebagai pengganti selisih antara biaya impor dengan HET. India mengal okasikan subsidi pertanian 10-

15\% dari total output pertanian. Di Malawi kebijakan subsidi input (benih dan pupuk) digunakan untuk mendukung program swasembada pangan, khususnya gandum dan tembakau, dan diversifikasi hasil panen guna mendorong peningkatan pendapatan masyarakat di wilayah perdesaan

Chibwana;2012).

(Christopher

Sementara itu Thailand Visi pembangunan pertanian menempatkan petani agar mendapat standar hidup 
yang lebih baik, masyarakat memiliki ketahanan pangan, dan negara memperoleh penerimaan".

Strategi kunci kebijakan pertanian Thailand meliputi: (1) pengembangan kualitas hidup petani (smart farmer); (2) pengembangan efisiensi produksi pertanian, manajemen, dan ketahanan pangan; dan (3) pengembangan sumber daya pertanian secara efisien, seimbang, dan berkelanjutan.

Strategi kunci dan sasaran utama kebijakan pertanian Thailand adalah peningkatan harga beras (rice pledging policy). Melalui kebijakan tersebut, pemerintah Thailand berupaya menjamin agar petani beras mendapatkan harga riil yang relatif tinggi di tingkat panen dan penggilingan padi. Untuk itu pemerintah Thailand menyiapkan mekanisme pembelian langsung beras petani. Di samping itu, pemerintah Thailand juga melaksanakan kebijakan peningkatan harga ekspor beras.

Kebijakan peningkatan harga di atas diiringi dengan program dan kegiatan peningkatan kualitas dan mutu beras, mulai dari tingkat petani/panen sampai ke tingkat eksportir/pasar dunia. Di samping itu, juga diimplementasikan kebijakan pendukung lain seperti fasilitas pupuk, benih, pengolahan, distribusi, pengemasan, dan pemasaran.

Pemerintah Thailand memiliki slogan "kitchen of the world" atau "dapur dunia". Slogan tersebut mengandung pengertian bahwa Thailand berupaya untuk memproduksi, mendistribusikan, dan mengekspor produk pertanian ke pasar dunia secara lengkap untuk memenuhi kebutuhan konsumen global terhadap "kebutuhan dapurnya", yaitu mulai beras, daging, telur, ikan, sayur, buah, bumbu, hingga penyedap dan produk lainnya.
Kebijakan Subsidi di Sub Sahara mempertimbangkan agroekologi dalam sistim pertanian serta mengkombinasikannya dengan layanan pendukung lainnya seperti penelitian dan pengembangan. Pengadaan dan pendistribusian pupuk bersubsidi harus dapat mendukung perkembangan pasar input. Pemerintah Sahara juga memiliki kebijakan pertanian melalui program bantuan tunai untuk meningkatkan pendapatan petani dan penggunaan input produksi, perkembangan liberalisasi pasar dan infrastruktur yang kuat, mendorong sektor swasta untuk ikut ambil bagian.

Sedangkan negara Afrika lainnya yaitu Tanzania menggunakan pendekatan model computable general equilibrium (CGE). Kebijakan subsidi pupuk dapat mendorong peningkatan produksi hasil tanaman dan lebih pada pola intensifikasi lahan, sedangkan liberalisasi perdagangan menstimulasi produksi produk-produk pangan dan ekstensifikasi lahan terkait proses produksi. Hanya sedikit dampaknya dari kedua kebijakan tersebut mempengaruhi distribusi dan erosi tanah (Grepperud).

Sedangkan studi kasus di banyak negara Afrika menunjukkan bahwa biaya kebijakan subsidi pupuk adalah sangat tinggi sehingga mendorong wacana mengalihkannya untuk pembangunan penelitian bidang pertanian, perluasan lahan pertanian, pelatihan, dan lain sebagainya. Bahkan kebijakan subsidi pupuk menawarkan sedikit solusi terhadap penggunaan pupuk yang rendah dan bahkan mendorong inefisiensi penggunaan pupuk karena harga jual pupuk yang relatif murah tersebut. Secara politik kebijakan subsidi tidak selalu memberikan dampak ekonomi yang efisien atau fiscally sustainable. Kebijakan harga subsidi seringkali menjadi second-best 
instrument dalam jangka pendek akibat kekurangan pupuk di pasar (Morris, ValerieA. Kelly, Ron J. Kopicki, and Derek Byerlee;2007).

\section{Pembahasan. \\ Kondisi kebijakan serta kontribusi subsidi pupuk pemerintah terhadap kesejahteraan petani sebagai jaminan ketahanan pangan nasional}

Kebijakan Subsidi Pupuk di Indonesia, agak berbeda jika dibandingkan pada belahan dunia lain, pada konstelasi makro, subsidi pupuk sedang dipertimbangkan kembali oleh pemerintah sebagai upaya memacu produksi pertanian setelah subsidi tersebut pernah dicabut beberapa tahun lalu. Melalui pendekatan persamaan simultan maka kebijakan subsidi pupuk disimulasi untuk menganalisis dampak menyuplai pasar input (Druilhe and Jesús Barreiro-Hurlé;2012), sedangkan penggunaan voucher input didalam mengakses pupuk bersubsidi belajar dari pengalaman pertanian di Nigeria pada tahun 2009 dapat meningkatkan akses petani terhadap pupuk bersubsidi, termasuk jumlah pemberian subsidi pupuk terhadap produksi dan ekspor kakao. Fenomena ini mengindikasikan bahwa kebijakan subsidi pupuk merupakan strategi kunci untuk menggerakkan perekonomian subsektor perkebunan kakao di Indonesia. Dengan kata lain, rencana pemberlakuan kebijakan subsidi pupuk masih dapat diharapkan untuk meningkatkan produksi dan ekspor kakao nasional (Arsyad, Bonar M. Sinaga, dan Syarifuddin Yusuf;2011).

Faktor kondisi lingkungan yang paling berpengaruh terhadap kebijakan subsidi pupuk adalah kondisi ekonomi yang diikuti oleh kondisi politik, sosial, dan teknologi. Sedangkan tujuan subsidi pupuk yang menjadi prioritas adalah ketersediaan pupuk kemudian peningkatan produksi pangan, peningkatan pendapatan petani, dan penyerapan tenaga kerja. Pola distribusi dan sistem distribusi pupuk yang menjadi pilihan pertama adalah pola subsidi secara tidak langsung melalui produsen dengan sistem distribusinya dilakukan oleh produsen kepada petani (Hendrawan, Arief Daryanto, Bunasor Sanim, dan Hermanto Siregar;2011).

Skema subsidi yang diformulasikan di Indonesia bukan secara mutlak diperuntukkan bagi masyarakat kelas bawah, baik dalam bentuk subsidi yang dapat menstimulus peningkatan produktivitas masyarakat kelas bawah, desain subsidi yang bisa membentuk modal sosial dan akan berkontribusi besar dalam perekonomian nasional di masa mendatang, maupun memberikan jaminan sosial secara berkala kepada masyarakat yang sangat miskin. Oleh karena itu, secara keseluruhan implementasi subsidi di Indonesia dalam kerangka mengatasi dampak kegagalan pasar kurang memerlihatkan hasil yang maksimal (Yustika;3).

Kebijakan subsidi pertanian khususnya mengenai perpupukan di Indonesia merupakan tulang punggung kebijakan subsidi bidang pertanian di Indonesia. Dimasa lalu pada program Bimas dan Inmas penggunaan pupuk merupakan salah satu komponen Panca Usaha Pertanian yang merupakan batang tubuh dari program Bimas. Walau berfluktuasi, nilai subsidi terus meningkat. Kebijakan pemerintah yang cenderung terus meningkatkan subsidi pupuk bertujuan untuk meningkatkan kinerja sektor pertanian, khususnya subsektor tanaman pangan. Kebijakan ini dilandasi pemikiran bahwa pupuk merupakan faktor kunci dalam meningkatkan produktivitas, dan subsidi dengan harga pupuk yang lebih murah 
akan mendorong peningkatan penggunaan input tersebut, juga subsidi pupuk untuk merespons kecenderungan kenaikan harga pupuk di pasar internasional dan penurunan tingkat keuntungan usaha tani. Meskipun memiliki tujuan yang mulia, kebijakan subsidi pupuk mengundang perdebatan. Ada yang berpendapat, kebijakan subsidi pupuk dinilai ber dampak positif terhadap peningkatan produktivitas sektor pertanian, Ada juga yang berpendapat, kebijakan subsidi pupuk dinilai tidak efektif dalam hal biaya, pencapaian petani target, kurang tepat waktu dan harga, bahkan cenderung mendorong penggunaan pupuk yang berlebihan.

Program subsidi pupuk menghadapi berbagai masalah dan kendala sehingga menurunkan efektivitasnya dalam mencapai tujuan. Paling tidak ada tiga masalah penting dalam program subsidi pupuk, yaitu (Susila;2010): 1) penyelewengan distribusi pupuk bersubsidi, 2) kesenjangan antara ketersediaan dan kebutuhan, dan 3) bias sasaran/target. Masalah pertama yang paling mendasar adalah sistem distribusi pupuk bersubsidi memberi peluang adanya penyelewengan distribusi. Akibatnya, petani yang seyogianya memperoleh pupuk bersubsidi sering mengalami kesulitan dari segi volume maupun harga. Hasil observasi pihak kepolisian menyebutkan paling tidak ada tujuh modus operandi penyelewengan pupuk bersubsidi, yaitu (Herman, AS): 1) melakukan penimbunan, 2) mengganti kemasan pupuk bersubsidi dengan nonsubsidi, 3) melakukan perdagangan antarpulau, 4) menyebarkan isu kelangkaan pupuk, 5) penyelundupan fisik dan administrasi, 6) memalsukan kuota kebutuhan, dan 7) menggeser stok dari satu daerah yang harganya lebih murah ke daerah yang harganya lebih tinggi.

Masalah kedua yaitu kesenjangan antara ketersediaan dan kebutuhan, muncul karena kesulitan dalam membuat data yang akurat mengenai kebutuhan pupuk bersubsidi. Prakiraan kebutuhan pupuk sering dibuat secara agregat dengan memperhitungkan luas tanam dan takaran pupuk secara umum. Kenyataannya, takaran penggunaan pupuk bervariasi, baik karena perbedaan luas lahan maupun tingkat kesadaran petani terhadap manfaat pupuk. Akibatnya, kebutuhan riil dengan ketersediaan pupuk sering berbeda nyata sehingga ada daerah yang kelebihan dan banyak yang kekurangan (Pusat Analisis Sosial Ekonomi dan Kebijakan Pertanian;2006).

Masalah ketiga berkaitan dengan azas keadilan. Petani kaya atau yang lahannya luas memperoleh pupuk bersubsidi jauh lebih banyak dibanding petani miskin atau berlahan sempit.hal ini menimbulkan pertanyaan bagaimana seharusnya kajian mengenai kebijakan perpupuk harus dilakuan untuk itu perlu dilakukan kajian bagaimana kebijakan perpupukan di sejumlah Negara.

\section{Perangkat hukum dalam mendukung subsidi.}

Sistem pemerintahan Republik Indonesia tidak terlepas dari pelaksanaan sistem-sistem di berbagai sektor yang mendukung pemerintahan, termasuk pula sistem hukum dan arah politik hukum dalam mencapai rencana dan tujuan bernegara. Abdul Hakim Garuda Nusantara mengatakan bahwa bagaimanapun hukum di Indonesia harus mengacu pada cita-cita masyarakat bangsa, yakni tegaknya negara hukum yang demokratis dan berkeadilan sosial (Mahfud MD;2010). 
Indonesia adalah negara hukum (reschstaat), penegasan ini dituangkan dalam Pasal 1 Ayat (3) Undang-Undang Dasar 1945 (UUD 1945). Konsekuensi ketentuan ini adalah bahwa setiap sikap, kebijakan, dan perilaku alat negara dan penduduk harus berdasar dan sesuai dengan hukum, hal ini menegaskan bahwa negara Indonesia bukan negara berdasarkan kekuasaan semata (Jimly Asshiddiqie). Sebagai Negara yang menganut sistem hukum eropa kontinental, konsepsi negara hukum negara Indonesia adalah negara hukum materiil atau negara hukum dalam arti luas yang bertujuan untuk kesejahteraan (welfare state) yang harus memberikan perlindungan kepada warga negaranya. Negara hukum kesejahteraan ini adalah merupakan tujuan atau cita-cita sebagaimana dinyatakan pembukaan UUD 1945 yaitu "melindungi segenap bangsa Indonesia dan seluruh tumpah darah Indonesia, dan memajukan kesejahteraan umum."

Pengertian hukum menurut Mochtar Kusumaatmadja adalah keseluruhan asas dan kaidah-kaidah yang mengatur hubungan manusia dalam masyarakat (Kusumaatmadja;2000). Mochtar Kusumaatmadja dalam mendefinisikan hukum tidak hanya mendefinisikannya sebagai asas dan kaidah saja, tetapi juga meliputi lembaga-lembaga dan proses yang mewujudkan berlakunya kaedahkaedah itu dalam masyarakat sebagai suatu kenyataan (Kusumaatmadja;2006).

Mochtar Kusumaatmadja mempunyai pendapat dan pemikiran bahwa hukum adalah sebagai sarana bagi pembangunan dan pembaharuan masyarakat (law as a tool of social engineering). Hal ini dikarenakan tujuan dari hukum adalah ketertiban dan tercapainya keadilan Selain itu Mochtar
Kusumaatmadja juga mengemukakan bahwa tanpa kepastian hukum dan ketertiban masyarakat yang dijelmakan olehnya tidak mungkin mengembangkan bakat-bakat dan dan kemampuan yang diberikan oleh Tuhan kepadanya secara optimal di dalam masyarakat (Kusumaatmadja).

Untuk mewujudkan cita-citanya sebagai negara hukum kesejahteraan maka negara menguasai cabang-cabang produksi yang penting dan yang menguasai hajat hidup orang banyak serta menguasai bumi, air dan kekayaan alam yang terkandung di dalamnya untuk dipergunakan sebesar-besarnya bagi kemakmuran rakyat. Hal ini dinyatakan dalam Pasal 33 Ayat (2) dan Ayat (3) UUD 1945.

Mencermati fungsi Negara hukum kesejahteraan tersebut, maka Negara kemudian menetapkan kebijakan subsidi. Terkait kebijakan subsidi pupuk khususnya kebijakan subsidi pertanian, signifikansi kebijakan subsidi di bidang pertanian ini terdapat dua tantangan besar. Pertama, perwujudan kedaulatan pangan, terkait dengan kemampuan dan perlindungan petani, dimana ditengah ketergantungan terhadap komoditas pangan impor dengan tantangan besar, subsidi diharapkan mampu meringankan beban biaya tanam para petani, diharapkan alokasi subsidi yang diberikan pemerintah akan mengurangi ongkos produksi untuk menanam yang dikeluarkan petani. Kedua berkaitan dengan peningkatan kapasitas dan perlindungan petani. Subsidi diharapkan mampu meringankan beban biaya tanam petani. Walaupun proporsi komponen subsidi dalam struktur usaha tanam relatif rendah (Direktorat Pangan dan Pertanian, 2013), namun melihat relatif rendahnya nilai tukar petani, alokasi subsidi yang diberikan pemerintah akan mengurangi ongkos produksi biaya 
tanam yang seharusnya dikeluarkan petani. Tentunya kebijakan pupuk subsidi harus dilihat dalam konteks dinamika kebijakan pupuk sesuai dengan periodisasi yang ada.

\section{Perkembangan subsidi di Indonesia.} Secara historis, pelaksanaan subsidi pertanian di Indonesia merupakan bagian langkah yang ditempuh pemerintah untuk ikut menerapkan gerakan revolusi hijau untuk mencapai swasembada pangan dengan memodernisasi sistem pertanian. Kebijakan ini diambil di tengah kesan terhadap perekonomian pertanian Indonesia masa lalu yang umumnya diliputi pesimisme terhadap kemampuan petani Indonesia menyerap teknik pertanian modern.

Subsidi, perbaikan teknis terhadap budidaya pertanian, dan dukungan kelembagaannya sebenarnya terbukti mendorong peningkatan dosis dan perluasan penggunaan pupuk dan mendorong pertumbuhan kenaikan produksi pangan (khususnya beras), hal ini terbukti bahwa Indonesia pernah berhasil mencapai swasembada pertamakalinya di tahun 1984.

Dimasa tiga dekade, sejalan dengan kebijakan subsidi, pemerintahan orde baru juga melaksanakan beberapa program untuk mendukung produktifitas tanaman padi, yaitu: (1) Bimbingan Massal (Bimas) 1964; Intensifikasi massal (Inmas) 1969; (3) Intensifikasi khusus (Insus) 1980; dan (4) Supra Insus 1987. Selain perbaikan teknis terhadap budidaya pertanian, berbagai program tersebut telah mendorong peningkatan dosis penggunaan pupuk sintetis pada lahan pertanian dan meningkatkan produktifitas lahan pertanian padi secara pesat dalam jangka pendek
Sejak program Bimas dan Inmas dilaksanakan, subsidi pupuk sudah menjadi komponen utama kebijakan subsidi bidang pertanian. Dalam program tersebut, penggunaan pupuk merupakan salah satu komponen Panca Usaha Pertanian yang merupakan batang tubuh dari program Bimas. Seperti yang dikemukakan sebelumnya, tujuan kebijakan pemerintah yang cenderung terus meningkatkan subsidi pupuk tidak lain adalah untuk meningkatkan kinerja sektor pertanian, khususnya subsektor tanaman pangan. Kebijakan ini dilandasi pemikiran bahwa pupuk merupakan faktor kunci dalam meningkatkan produktivitas, dan subsidi dengan harga pupuk yang lebih murah akan mendorong peningkatan penggunaan input tersebut. Pemberlakukan subsidi pupuk bertujuan menekan biaya yang akan ditanggung petani dalam pengadaan pupuk sehingga petani tidak kesulitan untuk memperoleh pupuk karena masalah biaya.

Pelaksanaan kebijakan subsidi pupuk di Indonesia telah diterapkan secara komprehensif dari perencanaan, pengaturan harga eceran tertinggi, jumlah subsidi, dan sistem distribusi pupuk. Namun demikian kebijakan tersebut belum mampu menjamin ketersediaan pupuk yang memadai di tingkat petani. Untuk itu pemerintah melakukan distribusi pupuk bersubsidi dari subsidi tidak langsung menjadi subsidi langsung kepada petani/kelompok tani sehingga manfaatnya dapat diterima langsung oleh petani.

Dalam kebijakan subsidi pupuk nasional, pupuk sintetis akan dikurangi secara bertahap sementara itu subsidi untuk pupuk organik dan NPK akan ditingkatkan. Meskipun menurut analisis dampak kebijakan subsidi pupuk terhadap pertanian ternyata pemerintah 
masih disarankan tetap memberikan subsidi pada pupuk TSP dan Urea kepada petani. Dalam analisa tentang dampak kebijakan subsidi pupuk terhadap keunggulan kompetitif dan tingkat keuntungan usaha tani padi yang juga telah diteliti Simpulannya menunjukkan bahwa kebijakan penurunan subsidi pupuk urea, SP-36, ZA, dan NPK Phonska hingga masih tetap memiliki keunggulan kompetitif. Oleh sebab itu kebijakan penurunan subsidi pupuk masih relevan dilaksanakan.

Berdasarkan hasil-hasil empiris tersebut menunjukkan jika kebijakan subsidi pupuk masih menguntungkan dan sudah jamak dilakukan pemerintahan negara-negara lain, mengingat dampaknya dalam meningkatkan produksi padi.

Pemerintah memberikan

kebijakan subsidi pupuk dalam rangka mencapai swasembada pangan. Fasilitasi pemberian subsidi pupuk diatur dalam Peraturan Menteri Pertanian Nomor 15/Permentan/Rc.110/1/2010 tentang Rencana Strategis Kementerian Pertanian 2010-2014, di mana skim subsidi pupuk adalah subsidi harga yang penyalurannya dilakukan dengan sistem pola tertutup yang menggunakan pendekatan Rencana Definitif Kebutuhan Kelompok (RDKK). Berbagai kelemahan penyaluran pupuk bersubsidi yang saat ini disiasati dengan meningkatkan peran aktif pemerintah daerah melalui (1) penerbitan Peraturan Gubernur dan Bupati/Walikota tentang alokasi kebutuhan pupuk bersubsidi sebagai penjabaran Peraturan Menteri Pertanian tentang kebutuhan dan harga eceran tertinggi (HET) pupuk bersubsidi untuk sektor pertanian, (2) pengawalan dan pendampingan serta validasi data RDKK, dan (3) optimalisasi peran Komisi Pengawasan Pupuk dan Pestisida (KP3) dalam pengawasan penyaluran pupuk bersubsidi di masing-masing wilayahnya.

Dengan berbagai kendala dilapangan kementerian pertanian mengusulkan pupuk yang selama ini subsidi menjadi tidak disubsidi lagi berdasarkan pola subsidi yang berlaku saat ini. Kendala yang terjadi dalam pelaksanaanya antara lain terdapatnya penjualan pupuk per-paket, harga pupuk bersubsidi yang tinggi, dan Bupati yang enggan menerbitkan izin penyaluran pupuk. Padahal berdasarkan Permendag Nomor 15 Tahun 2013, produsen seharusnya menyalurkan pupuk melalui distributor dan penyalur di kelompok tani yang ditunjuk. Penyaluran pupuk ke kelompok tani tersebut berdasarkan RDKK sesuai Permentan Nomor 122/Permentan/SR.130/11/2013.Kond isi ini pada akhirnya menyebabkan masa tanam padi tertunda.

Pupuk menjadi faktor penting dan strategis dalam meningkatkan produktivitas tanaman. Selain itu pangsa biaya pupuk mencapai 14 hingga 25 persen dari total biaya usaha tani. Menurut Wakil Ketua Badan Kehormatan DPR RI, Siswono Yudo Husodo, perlu ada alternatif pengalihan subsidi pupuk jika memang subsidi pupuk akan dihapus. Di negara lain, seperti Malaysia dan India, penghapusan subsidi pupuk justru meningkatkan potensi di sektor lainnya. Sedangkan menurut Wakil Ketua Komisi IV DPR RI, Herman Khaeron, bahwa pupuk bersubsidi yang banyak digunakan petani adalah pupuk urea, sehingga menyarankan untuk mengevaluasi produktivitas pupuk bersubsidi tidak seluruh pupuk dan jika memungkinkan dipilih satu jenis pupuk saja yang disubsidi. Hasil simulasi kebijakan penghapusan subsidi pupuk berdampak negatif terhadap produksi padi dan beras. 
Berdasakan penelitian dari Andriati dan Wayan Sudana menjelaskan bahwa agar pendapatan dan kesejahteraan petani lebih terjamin maka pemerintah lebih baik mengimplementasikan kebijakan subsidi HET pupuk urea dan insentif HPP secara bersamaan. Sedangkan untuk mempertahankan swasembada beras maka kebijakan yang harus ditempuh adalah peningkatan produksi beras yang disertai dengan diversifikasi pangan dan pemantapan program keluarga berencana.

Kaitannya kebijakan subsidi pupuk terhadap swasembada padi, arah pembangunan ketahanan pangan adalah untuk menjaga ketahanan dan kemandirian pangan nasional dengan pengembangan kemampuan produksi dalam negeri yang didukung oleh kelembagaan ketahanan pangan yang mampu menjamin pemenuhan kebutuhan pangan yang cukup di tingkat rumah tangga, baik jumlah, mutu, keamanan, maupun harga yang terjangkau, serta didukung oleh sumbersumber pangan yang beragam sesuai dengan keragaman lokal. Untuk mencapai target-target tersebut, upaya yang telah dan sedang dilakukan pemerintah antara lain adanya enam inti program aksi ketahanan pangan, yaitu lahan, infrastruktur, penelitian dan pengembangan, investasi, pangan dan gizi, serta perubahan iklim.

Berkaitan dengan upaya menuju swasembada pangan, pemerintah telah menetapkan target dan sasaran dari komoditas pangan utama hingga tahun 2014. Swasembada berkelanjutan ditargetkan khusus untuk komoditas padi dan jagung di mana sasaran peningkatan produksinya harus dipertahankan minimal sama dengan peningkatan permintaan di dalam negeri.
Secara khusus strategi untuk mencapai swasembada berkelanjutan padi akan dilakukan melalui (1) percepatan peningkatan produktivitas padi sawah, padi rawa/lebak, serta padi gogo dengan menitikberatkan pada area dengan tingkat produktivitas di bawah rata-rata nasional/propinsi/kabupaten dan (2) ekstensifikasi areal tanam terutama untuk padi gogo dan padi rawa/lebak yang dilakukan melalui pemanfaatan lahan peremajaan Perhutani dan Inhutani maupun pembukaan lahan/cetak sawah. Adapun wilayah sebaran produksi padi di wilayah Indonesia meliputi NAD, Sumatera Utara, Sumatera Barat, Sumatera Selatan, Lampung, Banten, Jawa Barat, Jawa Tengah, DIY, Jawa Timur, Bali, NTB, Kalimantan Barat, Kalimantan Selatan, Sulawesi Tengah, dan Sulawesi Selatan.

Dukungan utama agar dapat menunjang keberhasilan pencapaian target swasembada padi/beras tersebut ditetapkan melalui Peraturan Menteri Pertanian Nomor 15/Permentan/Rc.110/1/2010.

Implementasi riilnya meliputi penyediaan pupuk, subsidi pupuk, benih/bibit, dan kredit/bunga, perluasan lahan 2 juta hektar untuk tanaman pangan, hortikultura, perkebunan, hijauan makanan ternak dan padang penggembalaan, dan investasi pemerintah dan swasta di bidang pertanian.

Oleh sebab itu berdasarkan simulasi kebijakan di dalam model penelitian ini, jika pemerintah melakukan penghapusan subsidi pupuk maka target swasembada padi tidak akan tercapai, bahkan hingga tahun 2017. Namun demikian jika kebijakan subsidi pupuk tersebut hanya diberikan kepada pupuk urea dan bukan pada pupuk TSP, maka swasembada padi masih dapat 
dicapai oleh Indonesia. Hal ini karena pupuk urea adalah pupuk yang paling banyak digunakan oleh petani dan menjadi pupuk dasar.

Subsidi pertanian berdampak positif terhadap (Susila;2010): 1) peningkatan modal petani, 2) pengembangan pasar pupuk yang sebelumnya belum berfungsi sehingga menekan biaya distribusi, 3) adopsi teknologi dengan mengurangi risiko dalam pembelajaran teknologi baru, meningkatkan efektivitas penyuluhan, dan organisasi petani, 4) peningkatan produktivitas petani, dan 5) perbaikan pendapatan usaha tani.

Di lain sisi dampak kurang baiknya adalah semenjak ditetapkannya kebijakan subsidi, sebagaimana sifat barang subsidi pada umumnya, telah menyebabkan pasar pupuk bersifat dualistik, yaitu pasar bersubsidi dan pasar non subsidi. Dualisme pasar antara pupuk bersubsidi dan nonsubsidi ini telah menimbulkan disparitas harga di pasar pupuk. Hal inilah yang kemudian mendorong terjadinya berbagai masalah (misalnya kelangkaan), maupun penyimpangan (seperti penyelundupan), sehingga kebijakan tata niaga yang diterapkan pemerintah secara terusmenerus disesuaikan dan mengikuti dinamika masalah yang muncul. Penyempurnaan terhadap kebijakan tata niaga inilah yang memunculkan dinamika yang secara otomatis membawa dampak pada kelembagaan tata niaga pertanian bersubsidi itu sendiri sampai saat ini.

\section{Subsidi dan kendalanya dalam penerapannya.}

Dilihat dari sudut pandang anggaran pemerintah, subsidi di sektor pertanian termasuk dalam subsidi non energi (Subsidi nonenergi terdiri atas subsidi pangan, subsidi pupuk, subsidi benih, subsidi PSO, subsidi bunga kredit program dan subsidi pajak ditanggung pemerintah (DTP). Dalam RAPBN 2016, alokasi subsidi non energi sebesar sebesar Rp80.406,4 miliar. Angka ini terbagi atas : subsidi pangan sebesar Rp20.993,4 miliar; subsidi pupuk sebesar Rp30.063,2 miliar; subsidi benih sebesar Rp1.023,8 miliar; subsidi PSO sebesar Rp3.752,5 milar; subsidi bunga kredit program sebesar Rp16.474,5 miliar; dan subsidi pajak ditanggung pemerintah (DTP) sebesar Rp8.099,1 miliar (sumber laporan KPK tentang Laporan Hasil Kajian Kebijakan Subsidi di Bidang Pertanian, Jakarta 2017. Yang dalam kenyataan terus meningkat dari waktu ke waktu (Persentase anggaran subsidi non energi 2010-2015). Memperhatikan besaran anggaran dan signifikansi dampak yang muncul, pembenahan atas tatakelola kebijakan subsidi menjadi keharusan. Urgensi perbaikan tidak terlepas dari belum efektifnya kebijakan subsidi. Kepentingan mengapa subsidi itu diberikan apakah sudah sesuai dengan kaedah hukum yang berlaku, yaitu sesuai dengan cita-cita negara kesejahteraan (welfare state) sebagaimana dituangkan dalam alinea ke-4 Pembukaan Undang-Undang Dasar 1945 yaitu untuk memajukan kesejahteraan umum, maka cabangcabang produksi yang penting bagi negara dan yang menguasai hajat hidup orang banyak dikuasai oleh negara untuk dipergunakan sebesar-besarnya bagi kemakmuran rakyat.

Dalam penyaluran pupuk bersubsidi, pemenuhan atas sisi ketepatan menjadi sebuah masalah yang relatif kompleks. Permasalahan yang kompleks tersebut sebenarnya dapat dikelompokkan kedalam 4 permasalahan utama, yaitu pada saat 
pendataan, penganggaran, penyaluran dan pengawasan.

Dalam bidang pengawasan urgensi dilakukannya kajian subsidi yakni belum optimal pengawasan atas implementasi program-program subsidi. Monitoring dan evaluasi atas berjalannya program subsidi belum sepenuhnya berjalan optimal (Komisi Pemberantasan Korupsi;2017). Dilapangan, belum optimalnya capaian program-program subsidi dipengaruhi pula oleh disain kebijakan yang telah ditetapkan. Lebih lanjut, ketepatan pendataan menjadi sebuah kendala yang dihadapi dalam pelaksanaan kebijakan subsidi. Dalam penebusan pupuk bersubsidi, kelompok tani/petani kerap berpedoman kepada dokumen usulan kebutuhan pupuk yang disampaikan kepada pemerintah daerah.

Berbicara tentang periodisasi kebijakan pupuk subsidi dalam dinamika kebijakan dapat dibagi dalam 3 (tiga) era utama yang berbeda yaitu terdiri dari Pertama Era Regulasi Pupuk Bersubsidi Awal (Tahun 1969-1998) pada kurun waktu tersebut sistim subsidi yang diberlakukan adalah subsidi harga, sumber pembiayaan berasal dari Anggaran Pendapatan dan Belanja Negara (APBN), Pupuk yang disubsidi adalah harga pupuk yang berasal dari impor dan produksi dalam negeri, periode kedua adalah Era Pasar Bebas (Free Market and Semiregulated) (Tahun 1998-2002) dipicu dengan terjadinya krisis ekonomi saat itu, subsidi harga dicabut, dimana sistim subsidi pada kurun waktu tersebut adalah subsidi harga bahan baku untuk pembuatan pupuk yaitu gas, dan yang ketiga adalah Era Regulasi Pupuk Bersubsidi Lanjutan (Tahun 2003- sekarang) yang berlaku adalah subsidi harga, yang dihitung dengan formula selisih antara harga eceran tertinggi dengan Harga Pokok Produksi dan biaya produksi dikalikan volume produksi yang merupakan angka subsidi yang ditanggung oleh pemerintah melalui APBN. Walaupun menurut penulis, sebenarnya ada satu lagi yang perlu ditambahkan dalam periodisasi kebijakan pupuk bersubsidi yaitu ketika pemerintah telah mulai merintis pembangunan pabrik pupuk urea dalam negeri untuk menyiapkan perluasan penggunaan pupuk.

Disamping periodisasi yang disampaikan tersebut diatas, masingmasing Penguasa pemerintahan memiliki gaya yang berbeda dalam mengimplementasikan kebijakan subsidi. Pada awal pemerintahan kemerdekaan pembangunan dibidang pertanian adalah dengan menasionalisasi semua semua sektor pertanian yang dulunya adalah milik Hindia Belanda, dalam menganalisa sosial ekonomi petani, Pemerintah memperkenalkan konsep hidup dengan kesederhanaan, dengan berbagai keterbatasan namun masih dapat bertahan hidup. Pada era berikutnya adalah pembangunan pertanian di tetapkan dengan menggunakan segmentasi secara bertahap meningkat yang terkenal dengan Rencana Pembangunan Lima Tahun (REPELITA), dan mencapai puncaknya pada REPELITA IV, dimana pada tahun 1984, Indonesia telah berhasil melaksanakan swasembada beras (Kesuksesan ini mendapat penghargaan dari FAO (Organisasi Pangan Dunia) ditahun 1985). Periode-periode berikutnya kebijakan pertanian antara lain terkait dengan perlunya lembaga yang dapat menyeimbangkan harga pasar pertanian yaitu dengan dibentuknya BULOG dan peranannya dalam mengantisipasi gejolak pasar. Periode berikutnya dikenal dengan program "revitalisasi pertanian" program ini berjalan sejak tahun 2007 yang difokuskan di Kawasan 
Indonesia Timur. Pada periode ini subsidi diberikan dihampir setiap lini kebijakan pemerintah termasuk pertanian. Di era reformasi, subsidi difokuskan tidak hanya pada komponen sarana produksi petani tetapi juga dialokasikan atas bunga usaha kredit program dan premi asuransi usaha tanam padi. Tidak dapat dipungkiri dengan berjalannya waktu, peran subsidi dalam membangun sektor pertanian semakin krusial. Subsidi yang diberikan pun semakin beragam. Subsidi pertanian tidak lagi terbatas pada pupuk, dan benih, namun juga diberikan terhadap bunga kredit program dan premi asuransi pertanian. Model kebijakan subsidi di bidang pertanian menganut pola subsidi input dan subsidi tidak langsung diberikan kepada petani. Subsidi disalurkan kepada petani melalui produsen komoditas barang/jasa yang disubsidi.

Implementasi pupuk bersubsidi telah dilaksanakan sejak tahun 1970-an sebagai upaya merealisasikan swasembada pangan. Program Pupuk Bersubsidi dialokasikan kepada petani dengan mengacu kepada Rencana Definitif Kebutuhan Kelompok (RDKK). Saat ini subsidi pupuk diperuntukkan bagi petani, pekebun, peternak, dan pembudidaya ikan dan/atau udang (Pupuk bersubsidi diperuntukkan bagi petani dan atau petambak yang telah bergabung dengan kelompok tani dan menyusun RDKK dengan ketentuan petani yang melakukan usaha tani di bidang tanaman pangan sesuai areal yang diusahakan setiap musim tanam; petani yang melakukan usaha tani di luar bidang tanaman pangan dengan total luasan maksimal dua (2) hektar setiap musim tanam; atau petambak dengan total luasan maksimal 1 (satu) hektar setiap musim tanam. (Lihat Permentan No. 60 tahun 2016 tentang Kebutuhan dan Harga Eceran Tertinggi Pupuk Bersubsidi untuk Sektor Pertanian tahun Anggaran 2016). Adapun jenis pupuk yang disubsidi meliputi pupuk urea, pupuk SP 36, pupuk ZA dan pupuk NPK. Secara nominal, anggaran subsidi pupuk relatif besar. Di tahun 2016, subsidi pupuk mencapai nilai Rp. 30 Trilyun.

Penyelenggaraan kebijakan pupuk bersubsidi melibatkan banyak institusi. Institusi yang terlibat merentang dalam pelbagai tingkatan, baik pada level pusat, daerah, maupun organisasi-organisasi di tingkatan lokal. Tiap institusi tersebut memiliki peran tersendiri di mana dengan berdasarkan ketentuan yang berlaku dapat dijabarkan sebagai berikut : Dewan Perwakilan Rakyat, bertugas untuk membahas anggaran pupuk bersubsidi dengan pemerintah. Badan Pemeriksa Keuangan pada akhir tahun, lembaga ini melakukan perhitungan volume dan penyaluran pupuk bersubsidi yang dilakukan oleh produsen pupuk bersubsidi yang dalam hal ini adalah 5 anak perusahaan PIHC yang terdiri dari PT Pupuk Sriwidjaja, PT Pupuk Kalimantan Timur, PT Petrokimia Gresik, PT Pupuk Kujang dan PT Pupuk Iskandar Muda. Kemundian Kementerian Keuangan, lembaga ini (a) Menetapkan pagu indikatif anggaran pupuk bersubsidi. (b) Mewakili pemerintah dalam pembahasan anggaran dengan DPR. (c) Menetapkan tata cara penyediaan, pencairan dan pertanggungjawaban dana subsidi pupuk. Selanjutnya Kementerian Pertanian (a) Menetapkan pedoman pelaksanaan penyediaan dan penyaluran pupuk bersubsidi. (b) Menetapkan harga eceran tertinggi pupuk bersubsidi.

Menetapkan alokasi dan realokasi pupuk bersubsidi di tingkat provinsi. (d) Menetapkan dan melakukan realokasi pupuk dalam skala antar provinsi. (e) 
Melakukan verifikasi dan validasi atas penyaluran pupuk bersubsidi. Kementerian BUMN, Menunjuk BUMN yang menjalankan tugas pelayanan publik (public service obligation/PSO). Kementerian Perdagangan Mengatur tatacara pengadaan dan penyaluran pupuk bersubsidi di bidang pertanian.

Ditingkat daerah, di Tingkat propinsi (a) Melalui Dinas Pertanian, melakukan evaluasi atas rencana definitif kebutuhan kelompok yang telah direkapitulasi di tingkatan daerah oleh pemerintah daerah kabupaten/kota untuk selanjutnya disampaikan ke Kementerian Pertanian. (b) Menetapkan dan melakukan realokasi pupuk dalam skala antar kabupaten/kota. (c) Melakukan verifikasi dan validasi atas penyaluran pupuk bersubsidi. (d) Melalui Dinas Perdagangan melakukan pengawasan atas peredaran pupuk bersubsidi. Pada tingkat pemerintah Daerah Kabupaten/Kota (a) Melalui

Dinas Pertanian, menghimpun dan memverifikasi rencana definitif kebutuhan kelompok yang diajukan oleh kelompok tani (b) Menetapkan dan melakukan realokasi pupuk. Dalam skala antar kecamatan. (a) Melakukan verifikasi dan validasi atas penyaluran pupuk bersubsidi. (b) Melalui

Dinas Perdagangan melakukan pengawasan atas peredaran pupuk bersubsidi. Pada tingkat Korporasi Pemerintah, PT Pupuk Indonesia Holding Company (PIHC) Mengatur alokasi pengadaan dan penyaluran pupuk bersubsidi di lingkungan anak perusahaannya. Produsen Pupuk Subsidi di lingkungan PIHC, (a) Memproduksi dan menyalurkan pupuk bersubsidi kepada petani melalui mitra-mitra distribusi yang bekerjasama. (b) Melakukan pengawasan atas pengadaan atas penyaluran pupuk bersubsidi. Institusi Non Kementerian/Lembaga,
Kelompok Tani (a) Dalam lingkup keanggotaannya, menghimpun data kebutuhan pupuk bersubsidi di tingkat petani. (b) Memberikan pengantar kepada petani dalam penebusan pupuk bersubsidi di tingkat kios/pengecer. Distributor (a) Menyalurkan pupuk bersubsidi ke kios/pengecer pupuk bersubsidi. (b) Melakukan pengawasan atas penyaluran pupuk bersubsidi di tingkat kios/pengecer. Kios/Pengecer Tempat penebusan pupuk bersubsidi bagi kelompok tani/petani

Mekanisme

Pelaksanaan

Kebijakan Pupuk Bersubsidi Di tahap perencanaan, terdapat empat institusi yang memegang peran pokok yakni Kementerian Pertanian, pemerintah daerah, PIHC dan kelompok Tani. Secara ringkas dapat dijelaskan sebagai berikut (Perbandingan Nilai Pupuk Usulan RDKK dengan Alokasi Anggaran Pupuk Bersubsidi Tahun 2014-2016 (dalam rupiah) semakin tahun semakin besar perbedaannya. Di tahun 2014 usulan 36 Trilyun (T) alokasinya $21 \mathrm{~T}, 2015$ usulannya $44 \mathrm{~T}$, alokasinya $36 \mathrm{t}$, ditahun 2016 Usulannya $63 \mathrm{~T}$ alolasinya $30 \mathrm{~T}$ ):

a. Kelompok tani dengan dibantu penyuluh pertanian, penyuluh, petugas teknis, Kepala Cabang Dinas(KCD) / Kepala Unit Pelaksana Teknis Daerah (KUPTD) dan didukung oleh kepala desa/lurah setempat menyusun Rencana Definitif Kebutuhan Kelompok (RDKK) atas pupuk bersubsidi.

b. Pemerintah kabupaten melalui dinas pertanian merekapitulasi usulan RDKK dari tiap kecamatan yang ada diwilayahnya. Usulan RDKK dari kelompok-kelompok tani dikompilasi untuk selanjutnya disampaikan pada pemerintah provinsi. Pemerintah provinsi merekap usulan kebutuhan pupuk bersubsidi dari tiap daerah 
kabupaten/kota untuk selanjutnya disampaikan kepada Kementerian Pertanian.

c. Kementerian Pertanian melalui Direktorat Pupuk dan Pestisida menyusun kebutuhan pupuk berdasarkan rekapitulasi RDKK yang disampaikan tiap provinsi.

d. Kementerian

Pertanian menyampaikan usulan volume pupuk kepada Kemenkeu sesuai dengan pagu anggaran yang disampaikan Kementerian Keuangan sebelumnya.

e. Dari hasil pembahasan anggaran antara pemerintah dan DPR, Kementerian Pertanian menyusun alokasi pupuk subsidi tiap provinsi. Secara bersamaan Kementerian Pertanian juga melakukan kontrak kerja dengan PT Pupuk Indonesia Holding Company (PIHC) dalam hal penyediaan pupuk bersubsidi.

f. Atas alokasi pupuk bersubsidi yang ditetapkan Kementerian Pertanian, gubernur menetapkan alokasi pupuk bersubsidi pada tingkat kabupaten/kota. Selanjutnya bupati/walikota menetapkan alokasi pupuk bersubsidi di tingkat kecamatan pada wilayahnya.

Sementara itu, di tingkat produsen pupuk, PIHC paska penandatanganan kontrak dengan Kementerian Pertanian melakukan beberapa hal berikut (Permendag No. 15 tahun 2003 tentang Pengadaan dan Penyaluran Pupuk Bersubsidi untuk Sektor Pertanian):

a. Menetapkan wilayah tanggung jawab dan alokasi pupuk subsidi bagi tiap produsen pupuk. Produksi pupuk bersubsidi dilakukan oleh anak perusahaan PIHC, dalam hal ini PT Pupuk Iskandar Muda, PT Pupuk Sriwidjaja, PT Pupuk Kaltim, PT Petrokimia, dan PT Pupuk Kujang. b. Melalui anak perusahaan, berdasarkan Surat Perjanjian Jual Beli (SPJB) ,produsen menunjuk distributor untuk melakukan pembelian, penyimpanan, penyaluran dan penjualan pupuk bersubsidi dalam partai besar di wilayah tanggung jawabnya. Atas dasar serupa, distributor menunjuk pengecer untuk melakukan kegiatan penjualan pupuk bersubsidi secara langsung kepada kelompok tani dan atau petani di wilayah yang menjadi tanggung jawabnya.

Pelaksanaan Penyaluran pupuk dilakukan secara berjenjang, dari lini I sampai dengan lini IV. Diferensiasi peran tiap lini sebagai berikut:

a. Lini I, merupakan lokasi gudang pupuk di wilayah pabrik produsen atau di wilayah pelabuhan tujuan untuk pupuk impor.

b. Lini II, merupakan lokasi gudang produsen di wilayah ibukota provinsi dan unit pengantongan pupuk atau di luar wilayah pelabuhan.

c. Lini III, merupakan lokasi gudang produsen dan atau distributor di wilayah kabupaten/kota yang ditunjuk atau ditetapkan oleh produsen.

d. Lini IV, merupakan lokasi gudang atau kios pengecer di wilayah kecamatan dan atau desa yang ditunjuk atau ditetapkan oleh distributor.

Dalam pelaksanaannya, ketika menebus pupuk bersubsidi, petani membayar sesuai Harga Eceran Tertinggi (HET), HET untuk pupuk bersubsidi dalam kemasan $50 \mathrm{~kg}$, $40 \mathrm{~kg}$, atau $20 \mathrm{~kg}$ di lini IV yang dibeli secara tunai oleh kelompok petani atau petani sesuai dengan ketentuan yang ditetapkan oleh Menteri Pertanian. 
Monitoring dan Evaluasi Penyaluran Pupuk Bersubsidi, dimana Pemerintah melakukan pelbagai upaya pengawasan atas pengadaan dan penyaluran pupuk bersubsidi. Salah satu upaya yang dilakukan pemerintah ialah dengan menetapkan komoditas pupuk sebagai barang dalam pengawasan. Hal ini diatur dalam Peraturan Presiden Nomor 77 tahun 2005 tentang Penetapan Pupuk Bersubsidi sebagai Barang dalam Pengawasan. Melalui kebijakan tersebut, pengadaan dan penyaluran pupuk bersubsidi menjadi bagian dari subyek pengawasan.

Di tingkat lokal, pengawasan atas pupuk bersubsidi dilakukan pula melalui institusi Komisi Pengawasan Pupuk dan Pestisida (KP3). KP3 merupakan wadah koordinasi pengawasan antar intansi dibidang pupuk dan pestisida baik tingkat provinsi maupun kabupaten/kota. Untuk meningkatkan kinerja KP3, pemerintah mengalokasikan dana bagi KP3 melalui Direktorat Jenderal Prasarana dan Sarana Pertanian.

Secara umum, lingkup pekerjaan KP3 di tingkat Provinsi mencakup hal berikut (Direktorat Jenderal Prasarana dan Sarana Pertanian 2016):

a. Rapat Koordinasi KP3 Provinsi.

b. Pembelian Sampel Pupuk dan Pestisida.

c. Analisa Sampel Pupuk dan Pestisida.

d. Pembinaan Pengawasan Pupuk dan Pestisida.

e. Pemasangan Call Center.

Sementara di tingkat kabupaten/kota, kegiatan KP3 yaitu:

a. Identifikasi penggunaan pupuk dan pestisida di tingkat kelompok tani (petani).

b. Rapat Koordinasi Komisi Pengawasan Pupuk dan Pestisida (KPPP). c. Pembinaan Pengawasan Pupuk dan Pestisida.

d. Identifikasi peredaran pupuk dan pestisida.

e. Penyusunan Laporan KP3.

Selain pengawasan yang dilakukan pemerintah, produsen maupun penyalur pupuk bersubsidi juga diberikan tanggung jawab atas ketepatan penyaluran pupuk. Porsi tanggungjawab dari para pelaku usaha tersebut di atur dalam Pasal 8 Peraturan Menteri Perdagangan No 15 tahun 2013 tentang Pengadaan dan Penyaluran Pupuk Bersubdisi di Sektor Pertanian. Dalam peraturan tersebut dicantumkan tanggungjawab dari masing-masing pelaku usaha sebagai berikut:

a. PT Pupuk Indonesia bertanggung jawab atas pengadaan dan penyaluran pupuk bersubsidi di dalam negeri untuk sektor pertanian secara nasional sesuai dengan prinsp enam tepat mulai dari lini I sampai dengan lini IV.

b. Produsen bertanggung jawab atas pengadaan dan penyaluran pupuk bersubsidi sesuai dengan prinsip enam tepat mulai dari lini I sampai dengan lini IV di wilayah tanggungjawabnya.

c. Distributor bertanggung jawab atas penyaluran pupuk bersubsidi mulai dari lini III sampai dengan lini IV di wilayah tanggungjawabnya.

d. Pengecer bertanggung jawab atas penyaluran pupuk bersubsidi kepada petani/kelompok tani di lokasi kios pengecer.

Selain pengawasan oleh pemerintah, monitoring dan evaluasi dilakukan pula oleh Badan Pemeriksa Keuangan (BPK). BPK melakukan pemeriksaan atas pengadaan, volume dan penyaluran pupuk bersubsidi.

Mekanisme

perencanaan komoditas pupuk dan benih bersubsidi 
memunculkan pelbagai masalah turunan di lapangan. Pola perencanaan alokasi subsidi yang berjalan saat ini menimbulkan kompleksitas masalah, tidak hanya bagi Kementerian Pertanian, namun juga produsen komoditas subsidi.

Bagi Kementerian Pertanian, pola perencanaan yang berjalan tidak memberikan ruang untuk menyesuaikan antara usulan kebutuhan komoditas subsidi dengan alokasi riil anggaran subsidi yang diterimanya. Dalam Program Pupuk Bersubsidi, paska keluarnya pagu definitif anggaran, Kementerian Pertanian menyerahkan detail pembagian alokasi komoditas subsidi kepada tingkat kabupaten/kota. Sayangnya, penetapan alokasi pupuk di level kabupaten/kota tidak menjangkau sampai level kelompok tani/petani. Penetapan yang dilakukan oleh bupati/walikota hanya membagi pupuk sampai kedalaman kecamatan.

Dalam Perencanaan Kebijakan, Mekanisme Perencanaan Alokasi Pupuk Tidak Mendukung Implementasi Kebijakan yang Efektif dan Efisien Mekanisme perencanaan komoditas pupuk memunculkan pelbagai masalah turunan di lapangan. Pola perencanaan alokasi subsidi yang berjalan saat ini menimbulkan kompleksitas masalah, tidak hanya bagi Kementerian Pertanian, namun juga produsen komoditas subsidi.

Bagi Kementerian Pertanian, pola perencanaan yang berjalan tidak memberikan ruang untuk menyesuaikan antara usulan kebutuhan komoditas subsidi dengan alokasi riil anggaran subsidi yang diterimanya. Dalam Program Pupuk Bersubsidi, paska keluarnya pagu definitif anggaran, Kementerian Pertanian menyerahkan detail pembagian alokasi komoditas subsidi kepada tingkat kabupaten/kota. Sayangnya, penetapan alokasi pupuk di level kabupaten/kota tidak menjangkau sampai level kelompok tani/petani. Penetapan yang dilakukan oleh bupati/walikota hanya membagi pupuk sampai kedalaman kecamatan. Adanya gap antara perencanaan dengan anggaran yang dialokasikan pada gilirannya rawan memunculkan beragam masalah turunan.

Pertama, diskresi kelompok tani dalam mengalokasikan pupuk bersubsidi dan benih bersubsidi. Tanpa panduan yang tegas dan transparan kepada publik, pengurus kelompok tani rentan memanipulasi penerimaan pupuk dan benih bersubsidi di tingkat petani.

Kedua, memunculkan isu kelangkaan pupuk bersubsidi. Adanya kesenjangan antara usulan dengan jatah alokasi pupuk bersubsidi acap menimbulkan persepsi kelangkaan pupuk di tingkat petani.

Ketiga, ekspektasi berlebih kelompok tani/petani kepada BUMN pelaksana Public Service Obligation (PSO).

Dalam halnya penebusan pupuk di lini IV, distributor pupuk dan kelompok tani mendasarkan pada dokumen RDKK. Menjadi persoalan sewaktu alokasi riil pupuk bersubsidi dengan dokumen RDKK berbeda. Distributor rentan menerima tuntutan dari kelompok tani/petani untuk menyediakan alokasi pupuk melebihi pasokan riil yang diterimanya.

Keempat, persoalan integritas data atas penyaluran pupuk bersubsidi di tingkat kelompok tani/petani.

Model perencanaan memunculkan kisruh data penyaluran pupuk subsidi di tingkat kelompok tani/petani. Dengan pola perencanaan yang ada saat ini, pemerintah tidak memiliki sumber informasi yang akurat atas angka riil penyaluran pupuk subsidi di tingkat petani. Hal ini menjadi keniscayaan mengingat data yang ada di level 
pemerintah bersumber dari dua entitas, produsen pupuk dan pemerintah daerah, yang mana masing-masing bertujuan menghasilkan informasi dengan peruntukkan yang relatif berbeda. Produsen melakukan konsolidasi data untuk mengetahui penyaluran pupuk yang telah tersalur sampai tingkat kios. Sementara, pemerintah daerah berupaya melakukan verifikasi dan validasi untuk mengetahui angka riil penyaluran pupuk bersubsidi di tingkat kelompok tani/petani (Pedoman Pendampingan Verifikasi dan Validasi Penyaluran Pupuk Bersubsidi tahun 2016).

Pelaksanaan Kebijakan dalam Mekanisme Penetapan HPP Komoditas Pupuk Bersubsidi Membuka Celah Korupsi dan Mendorong Inefisiensi di Tingkat Produsen.

Dalam praktik, HPP terbagi menjadi dua, yakni HPP awal dan HPP audited. HPP awal ditetapkan oleh Menteri Pertanian. HPP awal dipergunakan sebagai acuan bagi pemerintah di tahun berjalan untuk membayar tagihan subsidi dari produsen pupuk. Setelah akhir tahun anggaran, Badan Pemeriksa Keuangan melakukan evaluasi guna menghitung riil HPP di tiap produsen pupuk bersubsidi. HPP hasil audited selanjutnya menjadi acuan untuk menilai adanya kekurangan bayar atau kelebihan bayar kepada produsen pupuk.

Penetapan HPP melalui pola tersebut membuka celah transaksional. Peluang transaksional kental muncul saat proses penilaian riil HPP, utamanya saat menentukan komponen biaya produksi yang layak masuk sebagai bagian penyusun HPP. Celah transaksional dalam proses evaluasi semakin terbuka mengingat aturan yang dipergunakan dalam mengevaluasi komponen HPP pupuk bersubsidi relatif bersifat umum dan multitafsir. Acuan utama dalam mengevaluasi kelayakan komponen HPP Pupuk Bersubsidi yang diajukan produsen adalah Permentan No. 1 tahun 2012 tentang Komponen Harga Pokok Penjualan Pupuk Bersubsidi Untuk Sektor Pertanian. Di 2012, BPK menemukan bahwa permentan No. 1 tahun 2012 masih memperhitungkan komponen biaya baik secara proporsional atau keseluruhan yang sebenarnya tidak dapat ditagihkan sebagai komponen biaya subsidi pupuk karena tidak terkait dengan proses produksi dan kegiatan subsidi pupuk. Selain itu, terdapat pembebanan biayabiaya yang belumsecara jelas diatur atau bersifat multitafsir dalam metode pembebanannya (Laporan Hasil Pemeriksaan dengan Tujuan Tertentu Semester I Tahun Anggaran 2012 Atas Subsidi Benih, Subsidi Pupuk, BLBU, BLP, CBN tahun 2011 pada Kementerian Pertanian, PT Sang Hyang Seri (Persero), PT Pertani (Persero), PT Berdikari (Persero), PT Berdikari (Persero) Serta Instansi Terkait lainnya di Wilayah Provinsi DKI Jakarta, Jawa Barat, Jawa Tengah, Jawa Timur, Sumatera Selatan, dan Sulawesi Selatan).

Akibatnya, evaluator rentan menggunakan diskresi saat menafsir kelayakan pembebanan dari item komponen produksi pupuk yang diajukan produsen (Acuan dalam mengevaluasi HPP mengacu pada Permentan No. 1 tahun 2012 tentang Komponen Harga Pokok Penjualan Pupuk Bersubsidi Untuk Sektor Pertanian). Adanya dua HPP juga potensial mendorong produsen utamanya di komoditas pupuk bersubsidi - mengajukan pembebanan berlebih pada keuangan negara. Adanya mekanisme koreksi HPP menyebabkan produsen tidak memiliki keterikatan memedomani HPP yang ditentukan diawal. Mekanisme koreksi HPP juga 
potensial mendorong produsen berlaku inefisien.

Celah inefisiensi tidak dapat dilepaskan pula dari relatif terbukanya item-item yang bisa dibebankan dalam komponen HPP Pupuk Bersubsidi. Membandingkan pembebanan biaya produksi pada program subsidi lain, pola pembebanan yang ada di komoditas pupuk menganut pola full costing. Dalam penyediaan pupuk bersubsidi, produsen memiliki ruang membebankan seluruh biaya produksi pupuk, termasuk pupuk yang dijual ke pasar komersial terakumulasi dalam HPP Pupuk Bersubsidi.

\section{Aspek kebijakan subsidi yang perlu pembenahan.}

Aspek Regulasi yang lain adalah (Analisis Kebijakan Pertanian. Volume 7 No. 2, Juni 2009) perlu adanya Sinkronisasi peraturan ditingkat Menteri, dengan memfungsikan RDKK sebagai Alat dalam Perencanaan dan Pengawasan Penyaluran Pupuk Bersubsidi Permentan No. 42/Permentan /OT.140/09/2008 menyatakan bahwa alokasi pupuk bersubsidi agar memperhatikan usulan yang diajukan oleh petani, pekebun, peternak, pembudidaya ikan dan atau udang berdasarkan RDKK disetujui oleh petugas teknis, penyuluh atau Kepala Cabang Dinas (KCD) setempat. Penyaluran pupuk bersubsidi dari Lini I ke Lini IV adalah mengikuti ketentuan Permendag No. 21/MDAG/PER/6/2008, selanjutnya penyaluran pupuk bersubsidi dari Lini IV (tingkat penyalur) sampai dengan petani/ kelompok tani diatur oleh Permentan No. 42/Permentan /OT.140/09/2008. Agar penyaluran pupuk bersubsidi tepat sasaran sesuai dengan rencana/alokasi, diperlukan dasar pertimbangan yang sama sebagai 'simpul' yang menghubungkan antara Permendag No. 21/M-DAG/PER/6/2008 yang mengatur penyaluran dari Lini I sampai IV dan Permentan No. 42/Permentan /OT.140/09/2008 yang mengatur penyaluran dari Lini IV ke petani atau kelompok tani dalam membangun distribusi tertutup. Proses perencanaan alokasi kebutuhan pupuk yang didasarkan atas RDKK perlu diikuti oleh penyaluran berdasarkan RDKK sehingga RDKK adalah 'simpul' yang dimaksud. Sebagai simpul, kata RDKK hendaknya juga dinyatakan secara eksplisit dalam Permendag 21/MDAG/PER/6/2008, sehingga dapat dengan mudah dipahami dan dilaksanakan serta diawasi oleh pihakpihak yang berkepentingan. Untuk meningkatkan akurasi data penguasaan lahan usahatani dan efektivitas penyusunan RDKK perlu dilakukan peningkatan kapasitas petani/kelompok tani melalui pendampingan/ pengawalan oleh penyuluh.

Penetapan Sanksi Pidana yang Jelas Bagi Pelanggar Ketentuan Penyaluran Pupuk Bersubsidi Berbagai bentuk pelanggaran penyaluran pupuk bersubsidi berupa pemalsuan pupuk bersubsidi, penjualan pupuk bersubsidi di luar peruntukkannya (kepada perusahaan pertanian/perkebunan dan industri atau bahkan penyelundupan ke luar wilayah), serta penjualan pupuk bersubsidi dengan harga eceran di atas HET sering terjadi. Sanksi yang jelas tersurat bagi pelanggar masih terbatas sebagai sanksi tindak pidana ekonomi; sebagaimana tercantum dalam Permendag No. 21/MDAG/PER/6/2008. Namun pada prakteknya, sanksi yang diberikan kepada pelaku pelanggar ketentuan (baik produsen, distributor, dan pengecer) hanya berupa sanksi administratif. Bagi produsen dikenakan 
sanksi administratif berupa peringatan tertulis dari menteri, bagi distributor diberikan sanksi administratif berupa peringatan tertulis dari bupati/walikota dan bagi pengecer dikenakan sanksi administratif berupa peringatan tertulis dari bupati/walikota. Bagi distributor dan pengecer yang tidak mentaati peringatan tertulis dikenakan sanksi pembekuan SIUP dan/atau pemutusan Kontrak. Sanksi di atas bagi pelanggar ketentuan perlu dipertegas dan memberikan efek jera. Penggunaan bantuan kepada aparat penegak hukum dimungkinkan untuk memproses pelanggaran sebagai tindak pidana sesuai peraturan perundangundangan (Permendag 21/M-DAG/PER/6/2008). Akan tetapi ketika akan pemprosesan sebagai tindak pidana, belum ada kejelasan peraturan perundangundangan yang mana yang dapat dijadikan acuan.

Memposisikan Kembali Penyaluran Pupuk Bersubsidi Sebagai Barang Dalam Pengawasan Pupuk bersubsidi adalah pupuk yang pengadaan dan penyalurannya ditataniagakan dengan Harga Eceran Tertinggi (HET) yang ditetapkan di penyalur resmi di Lini IV (Permentan No. 42/Permentan /OT.140/09/2008) dan ditetapkan sebagai barang dalam pengawasan (Perpres RI No.77 Tahun 2005). Dengan penetapan HET, marjin (fee) yang diterima distributor di Lini III dan penyalur di Lini IV dibatasi dan kecil, berkisar Rp.30 - 40 / Kg atau antara 2,53,5 persen dari modal yang harus dikeluarkan. Marjin ini sebenarnya sangat tidak menarik bagi distributor dan pengecer dibandingkan harus memperdagangkan barang konsumtif lain yang biasanya ditetapkan dengan marjin keuntungan antara 15-20 persen. Dalam Permendag 21/MDAG/PER/6/2008 disebutkan bahwa yang dimaksud pupuk bersubsidi adalah pupuk yang pengadaan dan penyalurannya mendapat subsidi dari pemerintah untuk kebutuhan petani yang dilaksanakan atas dasar program pemerintah di sektor pertanian (dalam hal ini adalah Departemen Pertanian). Hal ini berarti bahwa pupuk bersubsidi diadakan oleh produsen pupuk atas pesanan dari petani/kelompok tani yang dikoordinir oleh Kantor Cabang Dinas Pertanian di tingkat kecamatan, Kantor Dinas yang membidangi pertanian di tingkat kabupaten/kota, Kantor Dinas yang membidangi pertanian di tingkat provinsi untuk sampai ke Departemen Pertanian. Dengan RDKK maka jenis, jumlah, waktu, pihak pemesan, serta pihak yang mengkoordinir pesanan pupuk bersubsidi menjadi jelas sehingga penyalurannya akan menjadi mudah karena dilaksanakan oleh yang mengkoordinir pesanan tersebut. Penyaluran pupuk bersubsidi dari produsen kepada lembaga yang ditunjuk oleh Pemerintah Daerah di Lini III untuk disampaikan kepada kelompok tani pemesan. Penyaluran secara langsung ini sangat dimungkinkan, dalam Permendag 21/MDAG/PER/6/2008 disebutkan bahwa apabila penyaluran pupuk bersubsidi oleh distributor dan/atau penyalur di Lini IV tidak berjalan lancar, produsen wajib melakukan penyaluran langsung (operasi pasar) kepada petani dan/atau kelompok tani di lini IV setelah berkoordinasi dengan bupati/walikota cq. Kepala Dinas yang membidangi pertanian.

Permasalah lain terkait dengan subsidi pupuk adalah meningkatnya Beban Keuangan Negara Sebagai Akibat Tertundanya Pembayaran Subsidi Pemerintah Kepada Produsen Pupuk di Lingkungan PT PIHC 
Penundaan pembayaran subsidi pupuk dari pemerintah kepada produsen pupuk akan meningkatkan porsi tanggungan keuangan yang mesti dibayarkan pemerintah. Situasi ini menjadi keniscayaan mengingat beban bunga menjadi satu dari sekian komponen penyusun harga pokok penjualan pupuk bersubsidi (Tagihan pembayaran pupuk subsidi dihitung dari selisih antara HPP(Rp/Kg) dengan HET (Rp/Kg) kemudian dikalikan dengan jumlah penyaluran pupuk bersubsidi).

Sampai dengan Juni 2016, tunggakan kewajiban bayar negara kepada produsen pupuk mencapai angka Rp. 14,9 Trilyun. Jumlah ini terbagi atas tunggakan pembayaran di 2014 sebesar Rp. 7,4 trilyun, dan tunggakan pembayaran di tahun 2015 sebesar Rp. 7,5 trilyun. Bagi produsen pupuk, tertundanya pembayaran selain mengakibatkan terganggunya arus kas di internal perusahaan, juga turut meningkatkan beban bunga yang mesti ditanggung perusahaan sendiri mengingat porsi pinjaman pembiayaan komersial dilakukan bersamaan dengan pembiayaan subsidi (Di 2015, kisaran suku bunga pinjaman yang diterima PT PIHC sebesar 9,5\%-12,50\%. Pada tahun tersebut outstanding utang jangka pendek PT PIHC per 31 Desember 2015 mencapai angka Rp. 17,52 triliun). Dalam mekanisme pengadaan dan penyaluran pupuk bersubsidi, produsen pupuk sedari awal menanggung penuh biaya produksi. Arus kas masuk yang diperoleh produsen atas pengadaan dan penyaluran pupuk bersubsidi bersumber dari penjualan pupuk bersubsidi pada distributor, pembayaran pemerintah atas tagihan penyaluran pupuk bersubsidi dan atau pembiayaan modal kerja yang diterima dari perbankan (Harga penjualan pupuk bersubsidi di tingkat distributor antar anak produsen di lingkungan PIHC dapat berbeda. Harga penjualan pupuk bersubsidi di tingkat distributor ditetapkan oleh PIHC de ngan memperhatikan Harga Eceran Tertinggi di tingkat kios/pengecer).

$$
\text { Meningkatnya HPP Pupuk }
$$

Bersubsidi sebagai Akibat Relatif Tingginya Harga Gas yang diterima Produsen Pupuk Bersubsidi

Secara eksisting, harga gas yang diterima produsen pupuk subsidi relatif tinggi. Dari total lima produsen pupuk bersubsidi, terkecuali PT Pupuk Kaltim, sebagian besar menerima harga gas di atas $6 \%$. Walaupun rata-rata harga kontrak gas sebesar 5,77 dollar AS per mmbtu-nya, namun angka tersebut terus meningkat. Hal ini menjadi keniscayaan mengingat kontrak gas yang dilakukan antara produsen pupuk dengan penyedia gas sebagian besar menganut skema harga tetap (fixed price) dengan menambahkan klausul eskalasi harga di setiap tahunnya (Supplier gas produsen pupuk bersubsidi sebagian besar merupakan anak perusahaan PT Pertamina. Adapun persentase nilai eskalasi gas dalam kontrak di tiap perusahaan pupuk berbeda. Rentang persentase kenaikan harga gas berada dalam rentang $2,5 \% \quad-\quad 4 \%$ setiap tahunnya). Tingginya harga gas yang diterima produsen pupuk sendiri tidak bisa dipisahkan dari belum optimalnya peran PIHC dalam mensupervisi kontrak penyediaan gas bagi produsen pupuk bersubsidi. Belum optimalnya peran PIHC setidaknya tercermin dari variasi skema kontrak harga gas di tiap produsen pupuk bersubsidi. Keragaman kontrak tentunya tidak dapat terhindarkan mengingat masing-masing produsen pupuk maupun supplier gas memiliki keunikannya tersendiri. Namun demikian, peran PIHC akan sangat diharapkan oleh anak perusahaan. Proyeksi strategis atas harga gas beserta 
perkembangan harga pupuk di pasar internasional tentunya menjadi input penting bagi anak perusahaan saat bernegosiasi maupun menyepakati harga gas dengan mitra penyedianya.

Solusi Kebijakan Pemerintah terkait dengan implementasi kebijakan subsidi pupuk, adalah pemerintah telah mengkaji ulang menyempurnakan sistem distribusi yang sudah ada. Salah satu solusi yang ditawarkan adalah melalui sistem Single Responsibility (SR). Single Responsibility (SR) merupakan sistem pengelolaan wilayah pemasaran, distribusi dan penyaluran pupuk yang dilakukan oleh satu produsen. Jika saat ini sistem yang diterapkan dalam pengelolaan wilayah pemasaran, distribusi dan penyaluran pupuk dapat dilakukan oleh beberapa produsen, maka dengan system SR, setiap wilayah berada di bawah satu tanggung jawab produsen. Dalam penerapan SR, penyaluran dan distribusi pupuk di wilayah Aceh hanya dan akan dilakukan oleh PIM saja. Namun, PKG tetap dapat memasok pupuknya di wilayah Aceh melalui distributordistributor yang ditunjuk oleh PIM. Hal yang melatarbelakangi diterapkannya SR di antaranya adalah belum akuratnya penyusunan RDKK, kurang efisien dan efektifnya distribusi yang berjalan saat ini, pendayagunaan sumber daya manusia yang belum optimal dan masih kurang jelasnya tanggung jawab pendistribusian per wilayah. Oleh karena itu, tujuan penerapan SR di antaranya adalah : (1) efisiensi dan efektifitas; (2) penghematan nilai subsidi; (3) kemudahan pengendalian dan pengawasan; (4) akurasi RDKK; (5) tanggung jawab atas suatu wilayah lebih jelas; (6) dan optimalisasi sumber daya manusia. Dengan diterapkannya SR maka perlu adanya penyesuaian kebijakan Peraturan Menteri Pertanian
No.01/Permentan/SR.130/1/2012 tentang Komponen Harga Pokok Penjualan Pupuk Bersubsidi untuk Sektor Pertanian dan Peraturan Menteri Keuangan No.209/PMK.02/2013 tentang Tata Cara Penyediaan, Pencarian, dan Pertanggungjawaban Dana Subsidi Pupuk. Penyesuaian kebijakan tersebut terkait adanya perubahan dalam hal jumlah distributor di masing-masing wilayah propinsi, besaran subsidi yang akan diberikan ke masing-masing distributor, jumlah alokasi pupuk yang ditetapkan di dalam RDKK, serta mekanisme penyaluran pupuk, subsidi dan pengawasan.

\section{Kesimpulan}

Kebijakan subsidi pupuk bagi petani masih tetap diperlukan dalam rangka mendorong produktivitas hasil pertanian. Meskipun demikian, penerapan distribusi pupuk bersubsidi perlu diawasi sehingga penyaluran pupuk bersubsidi dapat terpenuhi secara 6 (enam) tepat yakni tepat jenis, jumlah, harga, mutu, waktu dan tempat. Melalui penerapan Single Responsibility (SR) diharapkan penyaluran pupuk bersubsidi di Indonesia dapat lebih tepat sasaran. Selain itu, tujuan lainnya seperti penghematan anggaran pemerintah untuk subsidi, kemudahan dalam pengendalian dan pengawasan, akurasi RDKK, kejelasan tanggung jawab di tiap wilayah serta optimalisasi sumber daya manusia juga dapat dicapai.

Pengawasan Program Subsidi Belum Berjalan Secara Optimal, Pengawasan program subsidi belum sepenuhnya melibatkan peran aktif dari seluruh pemangku kepentingan. Berdasarkan tata kelola perusahaan yang baik, maka pola pengawasan idealnya melibatkan partisipasi aktif dari pemerintah, pelaku usaha dan komunitas / masyarakat. Kondisi saat ini fungsi- 
fungsi pengawasan relatif lebih banyak diselenggarakan oleh entitas pemerintah dan korporasi, yang mana pelaksanaannya-pun masih terbatas, Sementara Di ranah pemerintahan, peran Kementerian Pertanian dalam memonitor pelaksanaan tugas KP3 masih terbatas.

Satu contoh mengenai peran masyarakat dalam pengawasan pupuk dapat disampaikan sebagai berikut. Pemerintah sudah membuat aturan untuk mengadakan pupuk bersubsidi, namun pada kenyataannya para petani masih sulit mendapatkan pupuk. Hal ini dipicu oleh oknum pasar yang berspekulasi dengan menimbun pupuk untuk kemudian dijual lagi apabila harga pupuk naik. Sehingga mereka yang mempunyai modal besar lebih mudah memperoleh pasokan pupuk dibanding para petani yang modalnya pas-pasan. Mekanisme distribusi pupuk bersubsidi dibuat sedemikian rupa sehingga pelaksanaan di lapangan dapat berjalan lancar. Tetapi pada kenyataannya banyak kebocoran. Pupuk bersubsidi jatuh ke tangan para spekulan pasar yang tidak bertanggung jawab. Kurangnya kontrol terhadap para pelaksana kebijakan membuat kebijakan yang dibuat pemerintah seolah-olah tidak dirancang dengan baik. Berkurangnya kepercayaan masyarakat petani terhadap upaya pemerintah dalam menyelesaikan masalah ini membuat para petani mencoba melakukan serangkaian percobaan untuk menemukan cara agar para petani dapat mandiri mengolah lahan mereka. Upayaupaya yang dilakukan adalah dengan mencoba mengganti pupuk urea dengan pupuk organik. Pupuk Organik ini terbuat dari kompos, kotoran sapi dan kambing. Setelah diuji cobakan, ternyata lahan pertanian yang menggunakan pupuk organik hasil panennya lebih banyak dan kualitasnya jauh lebih baik. Apalagi didukung dengan penelitian tentang hasil pertanian atau perkebunan yang menggunakan pupuk organik lebih aman bagi kesehatan manusia dibanding dengan yang menggunakan pupuk non organik. Hal ini membuat masyarakat yang sadar betapa pentingnya kesehatan dengan jalan memilih bahan makanan yang aman dan bebas dari bahan-bahan kimia lebih memilih produk-produk yang alami dan aman bagi kesehatan. Lahan pertanian yang menggunakan pupuk organik. Berdasarkan hasil tersebut, seharusnya Pemerintah mulai melirik alternative lain bagi penggunaan pupuk, karena ternyata produsen tidak bisa mencukupi kebutuhan pupuk bagi petani secara nasional. Kebijakan tentang pupuk bersubsidi bagi petani harus dibahas lagi mekanisme pelaksanaan dan pendistribusiannya kepada yang betulbetul membutuhkan. Oleh karena itu diperlukan peran serta masyarakat untuk mengontrol pelaksanaan setiap kebijakan yang diambil oleh Pemerintah atau pemilihan instrumen kebijakan pemerintah, sehingga pelaksanaan setiap program atau kebijakan dapat tepat guna, tepat cara, dan tepat sasaran

Tidak berbeda jauh kendalanya di sisi BUMN pelaksana program subsidi, pengawasan yang dilakukan juga belum mampu memotret implementasi prinsip 6 T secara utuh. Dalam praktek belum terlalu terlihat pada pengawasan Program Pupuk Bersubsidi. Produsen pupuk menitikberatkan monitoring dan evaluasi pada rantai distribusi yang bersinggungan langsung dengan masingmasing produsen pupuk, yaitu tingkat distributor. Sedangkan pengawasan produsen atas penyaluran pupuk di lini IV memang masih terbatas. Realitas di lapangan menunjukkan bahwa porsi monitoring dan evaluasi pada unit distribusi terendah (kios/pengecer) 
lebih banyak diserahkan pada distributor. Dalam beberapa kasus belum optimalnya produsen dalam menjalankan fungsi pengawasan dipengaruhi pula oleh terbatasnya tenaga pengawas tingkat lokal yang dimiliki. Di beberapa kabupaten/kota, produsen pupuk bahkan tidak memiliki tenaga pengawas.

Realitasnya, efisiensi dan efektivitas pelaksanaan programprogram yang termuat dalam kebijakan subsidi masih menuai pelbagai masalah, seperti disain program subsidi belum mendukung implementasi kebijakan yang efektif dan efisien. Disain program belum mengantisipasi atau memberikan solusi atas dinamika permasalahan yang muncul di lapangan. Hal ini secara eksplisit dapat dicermati dari imbas persoalan yang muncul akibat dari gap antara dokumen perencanaan dengan alokasi riil komoditas subsidi di tingkat petani. Pelaksana di tingkat daerah (pemerintah daerah maupun BUMN pelaksana) kerap dituntut secara mandiri menyelesaikan permasalahan yang timbul. Disini perlu segera dibuat standard operating procedure dalam pembebanan kewajiban pelayanan publik atau Public Service Obligation (PSO) yang memuat mekanisme, pengelolaan serta kewajiban dan hak penerima tugas PSO.

Jika diperlukan perubahan model pembebanan PSO, khususnya mengenai pemisahan adminstrasi antara aktivitas PSO dan aktivitas Komersial meliputi pemisahan fungsi pengelolaan uang, pengelolaan persediaan dan pengelolaan pencatatan. Terkait dengan ini perlu dibuat struktur organisasi diikuti dengan job description dan jangkauan pengawasan untuk masing-masing individu dalam organisasi. Kiranya perlu juga dijajagi peran koperasi, BUMD, termasuk swasta untuk dapat dilibatkan dalam penugasan pelayanan kepada publik.

Implementasi kebijakan yang dilaksanakan selama ini belum mampu menjadikan program-program subsidi terlaksana secara efektif dan efisien, masih terdapat celah untuk timbulnya penyelewengan. Hal ini tergambarkan dalam mekanisme penetapan HPP yang membuka ruang transaksional. Lebih lanjut, pola HPP awal dan HPP final dalam prakteknya potensial mendorong pelaksana program berlaku inefisien. Masalah lain yang muncul dalam tataran implementasi ialah realisasi pembayaran subsidi kepada BUMN pelaksana PSO belum dilaksanakan dengan pola yang tepat. Akibatnya dalam hal Program Pupuk Bersubsidi, untuk periode 20142015, negara masih menunggak pembayaran Rp. 14,9 trilyun kepada produsen pupuk. Nilai tersebut tentunya akan semakin meningkat mengingat beban bunga menjadi bagian yang diperhitungkan pula dalam menghitung HPP pupuk bersubsidi.

Pengawasan

terhadap penyelenggaraan program subsidi belum berjalan optimal. Lemahnya koordinasi di antara menteri terkait. Kelemahan koordinasi ini membuat sistem pengawasan dan distribusi belum optimal. Disamping juga pengawasan program subsidi belum melibatkan peran aktif seluruh pemangku kepentingan. Penyusun maupun pelaksana kebijakan belum sepenuhnya melakukan upaya-upaya untuk memastikan implementasi program subsidi mencapai hasil sesuai tujuan yang ditetapkan.

Atas persoalan yang muncul di tiap program subsidi pertanian, beberapa langkah perlu diambil agar program pertanian tidak menimbulkan kebocoran baik ditingkat pusat maupun ditingkat daerah antara lain : 
$\begin{array}{rlr}\text { Kementerian } & \text { Pertanian } & \text { perlu } \\ \text { mengintegrasikan } & \text { Program } & \text { Benih }\end{array}$ Bersubsidi dan Program pupuk, Benih Unggul Bantuan Langsung secara terpadu. Penyatuan Program subsidi pupuk, Benih Bersubsidi dan Program Benih Unggul Bantuan Langsung diperlukan untuk meningkatkan efektivitas pelaksanan program. Penyatuan menjadi hal krusial dilaksanakan karena tujuan, target dan karakter program subisidi pupuk, penyaluran Program Benih Bersubsidi dan Benih Unggul Bantuan langsung relatif serupa. Urgensi penyatuan juga semakin menjadi sebuah keharusan mengingat tiga program tersebut dikelola dalam satu payung direktorat jenderal. Perlu suatu BUMN Pangan Holding Company yang dapat mengintegrasikan semua kegiatan BUMN yang berkaitan dengan pengelolaan pangan supaya dalam satu komando dan inline dalam mencapai tujuan

Dalam rangka mengantisipasi hal tersebut kiranya perlu dijajagi pembentukan BUMN Pangan Holding Company adalah: strukturnya adalah PT Pupuk Indonesia menjadi Operating Holding BUMN Pangan yang membawahi anggota Holding PT Pupuk Indonesia saat ini, PT Sang Hyang Seri, PT Pertani, Perum Bulog dan PT BGR. Atau dibentuk Perusahaan Baru BUMN Pangan Holding Company yang membawahi PT Pupuk Indonesia, PT Sang Hyang Seri, PT Pertani, Perum Bulog dan PT BGR. Dengan cara ini maka terdapat koordinasi yang lebih inten jika Negara memiliki kebijakan baru atau membuat strategi yang paling optimal tentang pangan. Peran dan Fungsi Lembaga Pangan dalam Sistem Ketahanan Pangan dalam kerangka UU No 18/2012 tentang Pangan dapat dilihat mulai Pasal 126 Dalam hal mewujudkan Kedaulatan
Pangan, Kemandirian Pangan, dan Ketahanan Pangan nasional, dibentuk lembaga Pemerintah yang menangani bidang Pangan yang berada dibawah dan bertanggung jawab kepada Presiden. Pasal 127 Lembaga Pemerintah sebagaimana dimaksud dalam Pasal 126 mempunyai tugas melaksanakan tugas pemerintahan dibidang Pangan. Pasal128 Lembaga Pemerintah sebagaimana dimaksud dalam Pasal 127 dapat mengusulkan kepada Presiden untuk memberikan penugasan khusus kepada badan usaha milik negara dibidang Pangan untuk melaksanakan produksi, pengadaan, penyimpanan, dan/atau distribus Pangan Pokok dan Pangan lainnya yang ditetapkan oleh Pemerintah. • Pasal129 Ketentuan lebih lanjut mengenai organisasi dan tatakerja lembaga Pemerintah sebagaimana dimaksud dalam Pasal126 sampai Pasal128 diatur dengan Peraturan Presiden.

Disamping perlu adanya perancangan terpadu dengan memadu padankan antara pola penyaluran pupuk dan benih bersubsidi, juga subsidi sebaiknya dilakukan secara langsung kepada petani, dimana penyaluran subsidi secara langsung diharapkan akan mengeliminir masalah-masalah turunan yang kerap muncul dalam pengadaan maupun penyaluran komoditas pupuk dan benih bersubsidi. Melalui subsidi langsung diharapkan dapat menghilangkan persoalan angka riil penyaluran subsidi di tingkat petani. Melalui subsidi langsung baik pemerintah pusat, pemerintah daerah maupun produsen komoditas subsidi lebih mudah dalam mengetahui aggregat penebusan sebuah produk komoditas subsidi di tingkat petani. Kesamaan sumber referensi menjadikan konsolidasi data lebih mudah. Lebih dari itu, penyaluran subsidi secara langsung 
juga diharapkan memangkas permasalahan yang muncul di tiap jenjang jalur distribusi sehingga akan berkontribusi menurunkan HPP komoditas subsidi.

Di tingkatan daerah, model subsidi langsung diharapkan aparat daerah lebih fokus menjalankan fungsi pembinaan guna meningkatkan produktivitas pertanian. Sumberdaya daerah untuk melakukan verifikasi maupun validasi atas angka riil penyaluran komoditas subsidi di tingkat petani diharapkan bisa dialokasikan untuk kegiatan produktif lainnya. Terpenting, melalui model subsidi langsung, petani memiliki kebebasan menggunakan alokasi subsidi sesuai dengan kebutuhan. Petani memiliki kemampuan mengatur porsi pemanfaatan dana subsidi, guna membeli pupuk bersubsidi sesuai kebutuhannya. Untuk mewujudkan subsidi langsung, validitas data petani penerima program subsidi harus dimutakhirkan. Pemutakhiran data diperlukan untuk memastikan individu yang memenuhi kriteria tercakup seluruhnya dalam program bantuan subsidi sekaligus sebagai sarana untuk meningkatkan kontrol atas penyaluran subsidi. Secara bersamaan infrastruktur pendukung dalam mendukung pola subsidi langsung harus segera disiapkan.

Pemerintah, melalui Kementerian Pertanian dan Kementerian Keuangan menetapkan satu Harga Pokok Penjualan pada tingkat perencaan, ditiap komoditas subsidi sebagai acuan pembayaran maupun evaluasi pembayaran subsidi. Yang pada pengawasannya dinilai akan bermasalah. Hal ini karena HPP tersebut ada 2 HPP yaitu HPP awal yang ditetapkan oleh Kementerian Pertanian dan HPP YANG telah diaudit oleh BPK. Khususnya pada saat penilaian biaya produksi. Jadi pada prinsipnya terdapat kesenjangan antara perencanaan dan anggaran yang dialokasikan, akan memunculkan permasalahan. Skema HPP yang final sifatnya akan menjadi sarana untuk terjadinya efisiensi.

Pemerintah, harus segera melunasi tunggakan pembayaran subsidi kepada PIHC. Percepatan pelaksanaan pembayaran tunggakan juga dapat menghindarkan terus tergerusnya modal dari produsen pupuk bersubsidi. Karena Pupuk Indonesia telah menjalankan tugasnya namun pemerintah belum juga melunasi kewajibannya, hal ini akan mempersulit perusahaan pupuk untuk berkembang. Terlebih lagi hal ini tetap berulang setiap tahunnya. Dampak langsung bagi Industri Pupuk jika tidak segera dibayar adalah akan menggerus keuangan industri ini dengan beban bunga dan terhambatnya aliran dana segar untuk investasi baru. Karena untuk membiayai aktivitas produksi dan penyaluran pupuk bersubsidi pun. perseroan tersebut menggunakan pinjamanan dari sektor perbankan.

$$
\text { Meskipun sesuai dengan }
$$

ketentuan bukan menjadi tanggung jawab PIHC dan anak perusahaannya, namun seharusnya PIHC dan anak perusahaannya harus meningkatkan peran supervisi atas kegiatan pengadaan dan pengawasan penyaluran pupuk bersubsidi sampai di tingkat kios, disamping juga pengawasan PIHC terhadap anak perusahaan.

PIHC, Kementrian terkait lainnya seyogianya meningkatkan pendampingan maupun asistensi dalam memberikan proyeksi maupun penyepakatan kontrak pengadaan gas. Karena harga gas merupakan unsur dominan. Ide menarik terkait dengan adanya dominannya harga gas seperti demikian, dalam rangka terbentuknya pabrik pupuk yang sehat maka dapat dijajagi kerjasama atau bentuk 
penggabungan perusahaan pupuk dengan pemilik gas (Pertamina), baik dalam bentuk merger, atau akuisisi.

Program pengawasan masyarakat terkait dengan program subsidi perlu juga dilakukan, untuk itu Kementerian Pertanian harus memperluas saluransalurannya agar pengawasan oleh masyarakat atas pelaksanaan seluruh program subsidi yang terkait dengan bidang pertanian. Perluasan saluran tersebut harus dibarengi dengan kejelasan-kejelasan informasi antara lain atas nilai riil alokasi subsidi yang diterima di tingkat petani.

Sebagai penutup terdapat pandangan dari beberapa pakar dan penulis sepakat tentang hal tersebut dalam pembangunan pertanian yaitu adanya visi besar terkait dengan kesepakatan bersama bahwa jika kita sepakat bahwa untuk mencapai kesejahteraan petani maka yang menjadi sasaran pokok adalah pembaruan kebijakan pembangunan pertanian, namun dalam kenyataannya jarang kita mendengar kata pertanian, Departemen Pertanian lebih banyak mengurus agribusiness dan tidak lagi mengurus agriculture, kita sering mengatakan bahwa farming is business. Pernyataan tersebut memang berlaku di negara lain, tapi bukan di Indonesia. Di Indonesia farming seharusnya sudah bukan menjadi bisnis karena sejatinya kehidupan pertanian atau mata pencaharian pertanian telah menjadi pilihan menghidupi puluhan juta petani, disitu ada nilai sosial dan budaya yang sangat luhur dan dalam tanpa menjadi bisnis.

\section{Daftar Pustaka.}

Arsyad Muhammad, Bonar M. Sinaga, dan Syarifuddin Yusuf, "Analisis Dampak Kebijakan Pajak Ekspor dan Subsidi Harga Pupuk terhadap
Produksi dan Ekspor Kakao Indonesia Pasca Putaran Uruguay", Jurnal Sosial Ekonomi Pertanian, 8(1), Februari 2011.

Analisis Kebijakan Pertanian. Volume 7 No. 2, Juni 2009 : 131-146

A.S., Herman, Djumarman, dan H. Sukesi.. Kajian Sistem Distribusi Pupuk Bersubsidi. Laporan Penelitian. Badan Penelitian dan Pengembangan Perdagangan, Jakarta, 2005.

Asshiddiqie, Jimly Prinsip-prinsip Negara Hukum, diunduh dari http://www.indopos.co.id/index.p $\mathrm{hp} /$ berita-indo-review/8299-

konstitusi-dan-nkri-bagi-

kesejahteraan-bangsa.html, pada tanggal 12 Februari 2018.

Badan Perencanaan Pembangunan Nasional, Laporan Akhir Kajian Kerangka Subsidi di Indonesia, Direktorat Keuangan Negara, 2007.

Chibwana, Christopher Monica Fisher, and Gerald Shively, "Cropland Allocation Effects of Agricultural Input Subsidies in Malawi", World Development, 40(1), 2012.

Druilhe Zoé and Jesús Barreiro-Hurlé, "Fertilizer Subsidies in Sub-Saharan Africa”, ESA Working Paper No. 1204, Agricultural Development Economics Division Food and Agriculture Organization of the United Nations, July 2012

Grepperud Sverre and Henrik Wiig, "A CGE Model with Endogenous Soil Fertility: Maize Trade Liberalization vs. Fertilizer Subsidies in Tanzania", Politics and Economics in Africa, NOVA Science: New York, no year.

Hendrawan Dudi S., Arief Daryanto, Bunasor Sanim, dan Hermanto Siregar, "Analisis Kebijakan Subsidi Pupuk: Penentuan Pola Subsidi dan Sistem Distribusi 
Pupuk di Indonesia", Jurnal Manajemen \& Agribisnis, 8(2), Oktober 2011.

Herman, A.S., Djumarman, dan H. Sukesi. Kajian Sistem Distribusi Pupuk Bersubsidi. Laporan Penelitian. Badan Penelitian dan Pengembangan Perdagangan, Jakarta, 2005.

Kusumaatmadja, Mochtar Pengantar Ilmu Hukum Suatu Pengenalan Pertama Ruang Lingkup Berlakunya Ilmu Hukum, PT Alumni, Bandung, 2000.

-----------Konsep-Konsep Hukum dalam Pembangunan, PT Alumni, Bandung, 2006.

Komisi Pemberantasan Korupsi, Laporan Hasil Kajian Kebijakan Subsidi di Bidang Pertanian, Jakarta 2017

Laporan KPK tentang Laporan Hasil Kajian Kebijakan Subsidi di Bidang Pertanian, Jakarta 2017.

MD, Mahfud Membangun Politik Hukum Menegakkan Konstitusi, Raja Grafindo Persada, Jakarta, 2010.

Morris, Michael ValerieA. Kelly, Ron J. Kopicki, and Derek Byerlee, Fertilizer Use in African Agriculture Lessons Learned and Good Practice Guidelines, The World Bank, Washington DC., 2007.

Pedoman Pendampingan Verifikasi dan Validasi Penyaluran Pupuk Bersubsidi tahun 2016.

Peraturan Menteri Pertanian No.19/Permentan/HK.140/4/201 5 tentang Rencana Strategis Kementrian Pertanian.

Permentan No. 60 tahun 2016 tentang Kebutuhan dan Harga Eceran Tertinggi Pupuk Bersubsidi untuk Sektor Pertanian.

Pusat Analisis Sosial Ekonomi dan Kebijakan Pertanian. Konstruksi Kebijakan Pupuk 2006. Bogor 2006.
Purwoto,Syafa'at N., A. M. Maulana, dan C. Muslim.. Analisis Besaran Subsidi Pupuk dan Pola Distribusinya. Laporan Akhir Penelitian, Pusat Analisis Sosial Ekonomi dan Kebijakan Bogor 2006.

Susila, Wayan R. Kebijakan Subsidi Pupuk ditinjau kembali, PT Riset Perkebunan Nusantara, Jalan Salak No. 1A, Bogor 2010.

W.R Hutagaol, P.,. Susila, dan S. Hartoyo.. Evaluasi Dampak Bantuan Langsung Benih Unggul dan Pupuk terhadap Usaha Tani dan Pengembangan Pedesaan. Laporan Penelitian, Fakultas Ekonomi dan Manajemen, Institut Pertanian Bogor. 2009.

World Bank. 2009. World Development Report: Agricultural for Development. World Bank. Washington. Lihat juga Eicher, C.K. and J.M. Staatz.. International Agricultural Development. The John Hopkins University Press. London, 1998.

Yustika Ahmad Erani, Refleksi Subsidi dalam Perekonomian Indonesia, Bisnis \& Ekonomi Politik, Vol. 9(3), Juli 2008.

Sjari,. Pengaruh Subsidi Harga Pupuk terhadap Pendapatan Petani: Analisis Sistem Neraca Sosial Ekonomi. Bank Indonesia, Jakarta,2007.

World Bank.. Fertilizer Subsidies in Indonesia, Policy Note. Indonesia Agriculture Public Expenditure Review, the World Bank, Jakarta. 2009. 